\title{
A Review on the Degradation of Pollutants by Fenton-Like Systems Based on Zero-Valent Iron and Persulfate: Effects of Reduction Potentials, $\mathrm{pH}$, and Anions Occurring in Waste Waters
}

\author{
Naveed Ahmed *, Davide Vione *(D), Luca Rivoira (D), Luca Carena, Michele Castiglioni (D) \\ and Maria Concetta Bruzzoniti *
}

Citation: Ahmed, N.; Vione, D.; Rivoira, L.; Carena, L.; Castiglioni, M.; Bruzzoniti, M.C. A Review on the Degradation of Pollutants by Fenton-Like Systems Based on Zero-Valent Iron and Persulfate: Effects of Reduction Potentials, $\mathrm{pH}$, and Anions Occurring in Waste Waters. Molecules 2021, 26, 4584. https://doi.org/10.3390/ molecules26154584

Academic Editor: Giorgio S. Senesi

Received: 17 June 2021

Accepted: 21 July 2021

Published: 29 July 2021

Publisher's Note: MDPI stays neutral with regard to jurisdictional claims in published maps and institutional affiliations.

Copyright: (c) 2021 by the authors. Licensee MDPI, Basel, Switzerland. This article is an open access article distributed under the terms and conditions of the Creative Commons Attribution (CC BY) license (https:// creativecommons.org/licenses/by/ $4.0 /)$
Department of Chemistry, University of Turin, Via Pietro Giuria 5, 10125 Turin, Italy; luca.rivoira@unito.it (L.R.); luca.carena@unito.it (L.C.); michele.castiglioni@unito.it (M.C.)

* Correspondence: naveed.ahmed@unito.it (N.A.); davide.vione@unito.it (D.V.); mariaconcetta.bruzzoniti@unito.it (M.C.B.); Tel.: +39-34-7639-1584 (N.A.)

\begin{abstract}
Among the advanced oxidation processes (AOPs), the Fenton reaction has attracted much attention in recent years for the treatment of water and wastewater. This review provides insight into a particular variant of the process, where soluble Fe(II) salts are replaced by zero-valent iron (ZVI), and hydrogen peroxide $\left(\mathrm{H}_{2} \mathrm{O}_{2}\right)$ is replaced by persulfate $\left(\mathrm{S}_{2} \mathrm{O}_{8}{ }^{2-}\right)$. Heterogeneous Fenton with ZVI has the advantage of minimizing a major problem found with homogeneous Fenton. Indeed, the precipitation of $\mathrm{Fe}(\mathrm{III})$ at $\mathrm{pH}>4$ interferes with the recycling of Fe species and inhibits oxidation in homogeneous Fenton; in contrast, suspended ZVI as iron source is less sensitive to the increase of $\mathrm{pH}$. Moreover, persulfate favors the production of sulfate radicals $\left(\mathrm{SO}_{4}{ }^{\bullet-}\right)$ that are more selective towards pollutant degradation, compared to the hydroxyl radicals $\left({ }^{\bullet} \mathrm{OH}\right)$ produced in classic, $\mathrm{H}_{2} \mathrm{O}_{2}$-based Fenton. Higher selectivity means that degradation of $\mathrm{SO}_{4}{ }^{\bullet-}$-reactive contaminants is less affected by interfering agents typically found in wastewater; however, the ability of $\mathrm{SO}_{4}{ }^{\bullet-}$ to oxidize $\mathrm{H}_{2} \mathrm{O} / \mathrm{OH}^{-}$ to ${ }^{\bullet} \mathrm{OH}$ makes it difficult to obtain conditions where $\mathrm{SO}_{4}{ }^{\bullet-}$ is the only reactive species. Research results have shown that $\mathrm{ZVI}$-Fenton with persulfate works best at acidic $\mathrm{pH}$, but it is often possible to get reasonable degradation at $\mathrm{pH}$ values that are not too far from neutrality. Moreover, inorganic ions that are very common in water and wastewater $\left(\mathrm{Cl}^{-}, \mathrm{HCO}_{3}{ }^{-}, \mathrm{CO}_{3}{ }^{2-}, \mathrm{NO}_{3}{ }^{-}, \mathrm{NO}_{2}{ }^{-}\right)$can sometimes inhibit degradation by scavenging $\mathrm{SO}_{4}{ }^{\bullet-}$ and/or ${ }^{\bullet} \mathrm{OH}$, but in other cases they even enhance the process. Therefore, ZVI-Fenton with persulfate might perform unexpectedly well in some saline waters, although the possible formation of harmful by-products upon oxidation of the anions cannot be ruled out.
\end{abstract}

Keywords: Fenton chemistry; zero valent iron (ZVI); waste water treatment; water matrices; pH

\section{Introduction}

Advanced oxidation processes (AOPs) are emerging alternative methods for the effective removal of organic and inorganic wastewater pollutants with high stability and/or low biodegradability. These processes are mainly based on the generation of highly reactive radical species, among which the most common one is the hydroxyl radical, ${ }^{\bullet} \mathrm{OH}[1]$. In homogenous systems, radical species are being generated through several ways including electron transfer during activation of oxidants by transition metals, photolysis, thermolysis, and sonolysis [2]. The most conventional homogenous AOP is the Fenton process, in which $\mathrm{H}_{2} \mathrm{O}_{2}$ is activated by ferrous ions to produce ${ }^{\bullet} \mathrm{OH}$ [3]. The AOPs operate at ambient temperature and pressure and are often able to induce complete degradation of pollutants into non-toxic products like $\mathrm{CO}_{2}, \mathrm{H}_{2} \mathrm{O}$, and inorganic salts [4].

The Fenton process is being widely used as a common AOP for the decomposition of organic and inorganic pollutants in wastewater [5]. As a robust, convenient, and easy method [6], the Fenton process can be used either to lower toxicity of wastewater or 
to decontaminate wastewaters to allow for their drainage to water bodies [5,7]. In the traditional homogeneous Fenton process, strong oxidants $\left({ }^{\bullet} \mathrm{OH}\right.$ and/or reactive highvalence $\mathrm{Fe}$ species, such as ferryl, $\mathrm{FeO}^{2+}$ ) are generated by reaction of $\mathrm{H}_{2} \mathrm{O}_{2}$ with soluble iron ions $\left(\mathrm{Fe}^{2+}\right)$ that act as catalysts in acidic conditions [8]. The use of soluble Fe salts $\left(\mathrm{Fe}^{2+}\right)$ in traditional Fenton gives the highest efficiency if we ignore the mass transfer limitations between active reagents [9]. The main drawback of the classical Fenton process is $\mathrm{Fe}(\mathrm{III})$ precipitation due to both catalyst $\left(\mathrm{Fe}^{2+}\right)$ oxidation and $\mathrm{pH}$ adjustment, which produces a sludge waste $[5,10,11]$. Indeed, $\mathrm{Fe}^{2+}$ remains dissolved even at neutral $\mathrm{pH}$ but $\mathrm{Fe}^{3+}$ disappears at $\mathrm{pH} \geq 4$ while forming ferric hydroxides sludge. Therefore, severe acidic conditions $(\mathrm{pH}<4)$ are required to maintain and carry out the process for practical applications, which demand high cost of reagents to acidify the effluents before treatment, and afterward neutralizing them before drainage [12].

To overcome the above-mentioned drawbacks, in the past decades many approaches have been made to proceed with better efficacy while using heterogeneous Fenton and Fenton-like systems. In heterogeneous Fenton reaction, different poorly soluble iron compounds $\left(\mathrm{Fe}_{2} \mathrm{O}_{3}, \mathrm{Fe}_{3} \mathrm{O}_{4}, \mathrm{FeO}, \mathrm{FeS}_{2}\right.$, etc.) are added as catalysts with $\mathrm{H}_{2} \mathrm{O}_{2}$ to decontaminate or degrade pollutants in aqueous solution $[4,5,9,13]$. Other alternatives to increase the efficiency of the Fenton reaction are to use supports for iron oxides or include Fe oxides into composite porous materials (clay, zeolites, activated carbon, polymers and multiwalled carbon nanotubes, Nafion films, pumice particles, ashes, and aluminates) $[4,5,14-17]$. The overall performance of the Fenton reaction may even be increased in such conditions because the support adsorbs the pollutant molecule and, in some cases, can also facilitate different pathways that generate radicals for pollutants degradation [5,18-20].

In heterogeneous Fenton-like systems, the generation of free radicals and/or other oxidizing species is achieved by using the heterogeneous catalyst together with ultrasound energy, magnetic field, ultraviolet radiations, microwave radiation, or a combination of them [5,21].

Zero-valent iron (ZVI) has attracted much attention by researchers among the catalysts used for Fenton-like or heterogeneous Fenton processes. ZVI is a promising material to be used for water and wastewater treatments, due to its eco-friendliness $[5,22]$, costeffectiveness [23], non-toxicity, and ability to transform different pollutants such as halogenated compounds $[5,24,25]$, nitrate $[26,27]$, heavy metals [5,26,28-31], phosphate [32], arsenic [33-36], phenol [37-39], polycyclic aromatic hydrocarbons [40,41], and dyes [7,42]. ZVI can be used either alone by exploiting its reductive (electron-donor) properties [39], or in combination with $\mathrm{H}_{2} \mathrm{O}_{2}$ in a heterogeneous Fenton reaction with production of oxidizing species and especially ${ }^{\bullet} \mathrm{OH}$ [42]. Last but not least, recent advances have focused on the combined use of ZVI with persulfate $\left(\mathrm{S}_{2} \mathrm{O}_{8}{ }^{2-}\right)$ or peroxymonosulfate $\left(\mathrm{SO}_{5}{ }^{2-}\right)$ to obtain a heterogeneous Fenton-like process, where the main aim is to generate the sulfate radical $\left(\mathrm{SO}_{4}{ }^{\bullet-}\right)$ as an alternative oxidizing agent to ${ }^{\bullet} \mathrm{OH}$. Compared to ${ }^{\bullet} \mathrm{OH}, \mathrm{SO}_{4}{ }^{\bullet-}$ is a bit less reactive but it is more selective [43,44]. This means that, in well-designed systems, the $\mathrm{SO}_{4}{ }^{\bullet-}$-based processes can achieve pollutant degradation with lesser interference from water components when compared to the ${ }^{\bullet} \mathrm{OH}$-based techniques (vide infra) [45].

Many water parameters have the potential to affect the performance of the ZVIFenton and Fenton-like systems towards pollutant degradation. They include, among others, solution chemistry, $\mathrm{pH}$, concentration of reagents, and involvement of different anions $[5,11,46,47]$. One of the most crucial operating parameters among all others is $\mathrm{pH}$, which controls the chemistry, the capacity to generate radicals, the catalyst behavior and the overall efficiency of virtually any Fenton process $[5,48,49]$.

This review addresses the effects of $\mathrm{pH}$ and of interfering ions (chloride, carbonate, bicarbonate and nitrate/nitrite, as important components of water and wastewater) on the Fenton-like process based on ZVI and persulfate (ZVI/PS), which has not been reviewed so far $[3,5,13,50]$. Furthermore, the formation of secondary pollutants is here discussed. We decided to focus on ZVI/PS instead of ZVI/peroxymonosulfate, which is also an effective technique, because ZVI/PS has been the object of more numerous studies that covered 
a wider range of conditions. Moreover, by focusing on PS it was also easier to compare the results of different studies.

$\mathrm{ZVI} / \mathrm{PS}$ is a promising process, which may combine the advantages of heterogeneous Fenton with the selectivity of $\mathrm{SO}_{4}{ }^{\bullet-}$. However, although the replacement of $\mathrm{H}_{2} \mathrm{O}_{2}$ with persulfate can reduce interferences by water components, it does not totally eliminate them. Moreover, pH still plays a key role because, in addition to affecting the overall Fenton efficiency, it also influences the reaction pathways by favoring the generation of ${ }^{\bullet} \mathrm{OH}$ vs. $\mathrm{SO}_{4}{ }^{\bullet-}$ as the main reactive species, as explored in the next section.

\section{Reactive Species: ${ }^{\bullet} \mathrm{OH}$ vs. $\mathrm{SO}_{4}{ }^{\bullet-}$ vs. ${ }^{\bullet} \mathrm{OH}+\mathrm{SO}_{4}{ }^{\bullet-}$}

One of the main features of the hydroxyl radical is its high reactivity towards most compounds that occur in water and wastewater [51]. On the one side, this warrants the possibility to degrade a wide array of contaminants in the framework of water treatment. At the same time, however, ${ }^{\bullet} \mathrm{OH}$ can be scavenged by many constituents of natural water and wastewater, such as organic matter and some inorganic anions (e.g., $\mathrm{Cl}^{-}, \mathrm{NO}_{2}{ }^{-}$, $\mathrm{HCO}_{3}{ }^{-}$, and $\mathrm{CO}_{3}{ }^{2-}$ ). Natural water constituents do not necessarily require oxidation for water to be properly decontaminated, thus their ability to scavenge ${ }^{\bullet} \mathrm{OH}$ will mostly inhibit the degradation of pollutants [52]. The consequence of ${ }^{\bullet} \mathrm{OH}$ scavenging by organic matter and inorganic anions, which act as interfering agents, is thus increased costs and/or a decrease in process efficiency [51].

A possible solution to the above problem is to look for alternative reactive species, which should be more selective than ${ }^{\bullet} \mathrm{OH}$ but, at the same time, ensure elevated reactivity and oxidizing power. The sulfate radical, $\mathrm{SO}_{4}{ }^{\bullet-}$, has interesting features because it has similar or even higher reduction potential compared to ${ }^{\bullet} \mathrm{OH}$, but at the same time it is more selective. Figure 1 reports the available literature data about the second-order reaction rate constants between the two radical species $\left({ }^{\bullet} \mathrm{OH}, n=713\right.$, and $\left.\mathrm{SO}_{4}{ }^{\bullet-}, n=119\right)$ and organic compounds, here indicated by the respective number of $\mathrm{C}$ atoms $[43,44]$. The comparison suggests that, on average, ${ }^{\bullet} \mathrm{OH}$ is more reactive compared to $\mathrm{SO}_{4}{ }^{\bullet-}$.

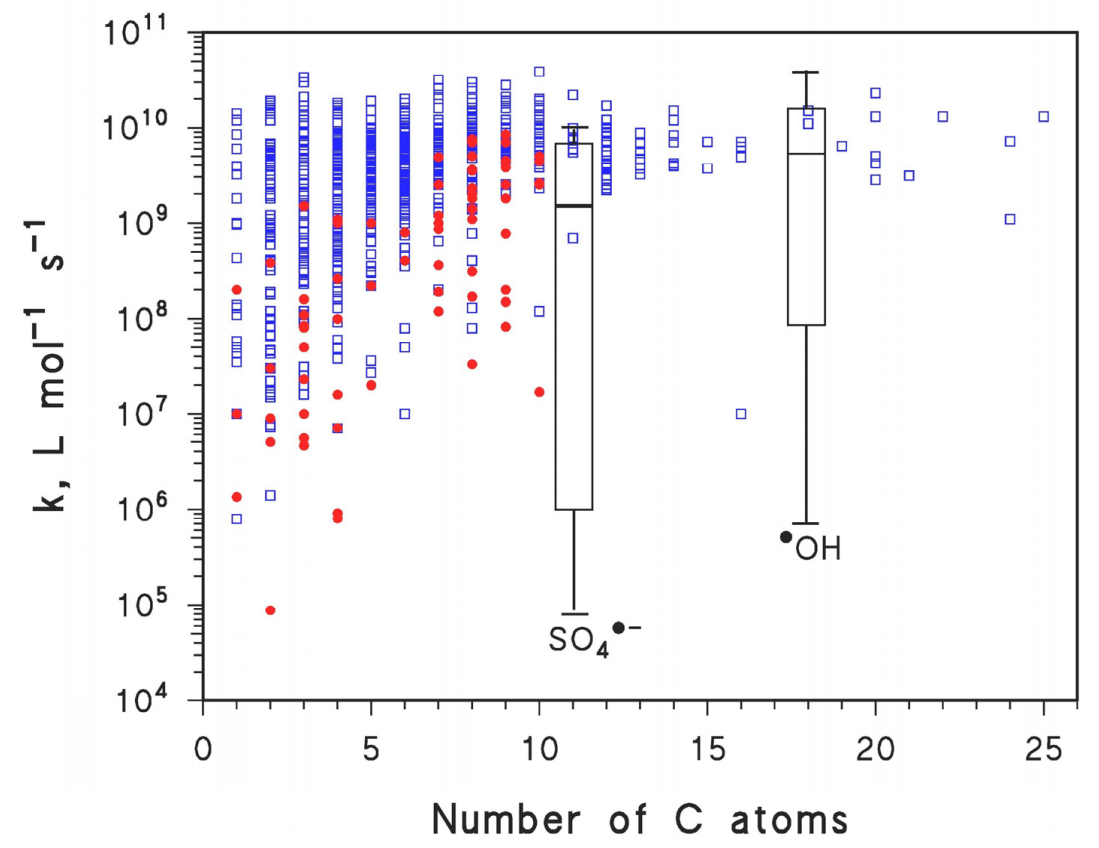

Figure 1. Second-order reaction rate constants $(k)$ of organic compounds with $\mathrm{SO}_{4}^{\bullet-}(\bullet, n=119)$ and with $\bullet \mathrm{OH}(\square, n=713)$, as a function of the number of carbon atoms (on average, compounds with more carbons are more reactive, which for instance justifies the use of a group contribution method to predict ${ }^{\bullet} \mathrm{OH}$ reactivity) $[43,44]$. In the summarizing diagrams, boxes represent the 5 th, 50th (median), and 95 th percentiles of the distribution, while the whiskers show the extreme values. 
Moreover, although the highest $\mathrm{SO}_{4}{ }^{\bullet-}$ reaction rate constants approach (and those of - $\mathrm{OH}$ slightly surpass) the value of $10^{10} \mathrm{~L} \mathrm{~mol}^{-1} \mathrm{~s}^{-1}$, which is near the diffusion-control limit in aqueous solution [43], the lowest rate constant values reach $10^{6} \mathrm{~L} \mathrm{~mol}^{-1} \mathrm{~s}^{-1}$ in the case of ${ }^{\bullet} \mathrm{OH}$ and $10^{5} \mathrm{~L} \mathrm{~mol}^{-1} \mathrm{~s}^{-1}$ in the case of $\mathrm{SO}_{4}^{\bullet-}$.

Overall, the reaction rate constants of $\mathrm{SO}_{4}{ }^{\bullet-}$ span 1-2 orders of magnitude more than those of ${ }^{\bullet} \mathrm{OH}$, and the equivalent percentiles correspond to lower values of the reaction rate constants in the case of $\mathrm{SO}_{4}{ }^{\bullet-}$. Therefore, $\mathrm{SO}_{4}{ }^{\bullet-}$ is both less reactive and more selective than ${ }^{\bullet} \mathrm{OH}$, which means that in the case of $\mathrm{SO}_{4}{ }^{\bullet-}$, it would be easier to find a contaminant or a group of contaminants having high reaction rate constant(s) with the radical transient, in a framework of interfering agents showing (on average) much lesser reactivity. The presence of interfering agents may thus have lesser impact on $\mathrm{SO}_{4}{ }^{\bullet-}$-based compared to - OH-based treatments [45], for which the reaction rate constants have the tendency to be more similar for target contaminants and interfering agents.

It is also interesting to highlight the reason why two radicals with similar reduction potentials $\left(\mathrm{E}^{\circ} \sim 2.6 \mathrm{~V}\right.$ in both cases) $[43,44]$ show different reactivity. The point is that $\mathrm{SO}_{4}{ }^{\bullet-}$ reacts exclusively or almost exclusively via electron transfer, which is easier and faster in the case of heteroatoms $(S, N)$ present on aromatic or aliphatic compounds, compared to inorganic species. This issue is depicted in Figure 2, showing that $\mathrm{SO}_{4}{ }^{\bullet-}$ is usually more reactive towards aromatics. Compared to $\mathrm{SO}_{4}{ }^{\bullet-},{ }^{\bullet} \mathrm{OH}$ can be involved in a wider range of reactions that, apart from electron abstraction, also include $\mathrm{H}$-atom abstraction and addition to double bonds and aromatic rings [44,52]. Therefore, ${ }^{\bullet} \mathrm{OH}$ is still able to react fast with compounds, for which the reactivity with $\mathrm{SO}_{4}{ }^{\bullet-}$ is rather poor. On this basis, the oxidative removal of many aromatic contaminants with $\mathrm{SO}_{4}{ }^{\bullet-}$ may provide a favorable scenario, where the contaminants themselves react fast with $\mathrm{SO}_{4}{ }^{\bullet-}$ and compete favorably with the interfering agents. Indeed, interfering agents usually include an important fraction of aliphatic as well as inorganic compounds.

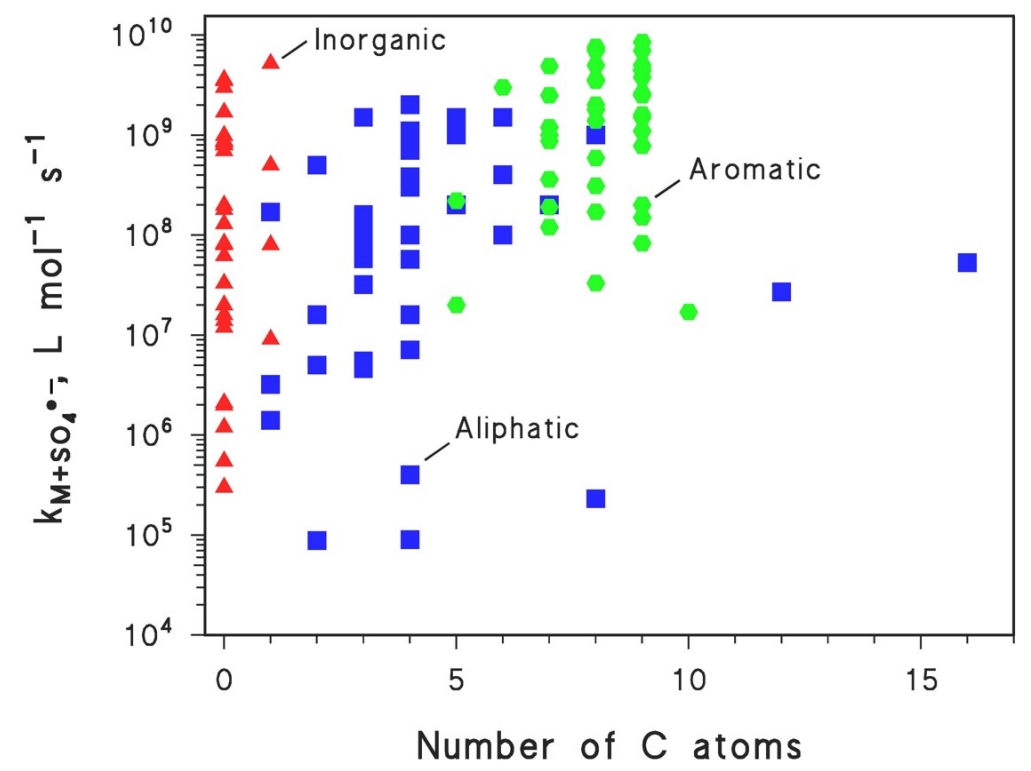

Figure 2. Second-order reaction rate constants $\left(k_{M+\mathrm{SO}_{4}^{--}}\right)$of inorganic $(\boldsymbol{\Lambda})$, aliphatic $(\boldsymbol{\square})$ and aromatic (-) compounds $\mathrm{M}_{\text {with }} \mathrm{SO}_{4}{ }^{\bullet-}$, as a function of the number of carbon atoms. Rate constant data were derived from the work in [44].

The above discussion accounts for the current interest in the development of $\mathrm{SO}_{4}{ }^{\bullet-}$-based advanced oxidation processes, as an alternative or as a complement to the ${ }^{\bullet} \mathrm{OH}$-based ones. Unfortunately, however, it is very difficult to devise a treatment technique that is based exclusively on $\mathrm{SO}_{4}{ }^{\bullet-}$. A first reason is that ${ }^{\bullet} \mathrm{OH}$ and $\mathrm{SO}_{4}{ }^{\bullet-}$ have very similar standard reduction potentials. Moreover, the reduction of ${ }^{\bullet} \mathrm{OH}$ is strongly enhanced in acidic conditions, while that of $\mathrm{SO}_{4}{ }^{\bullet-}$ is much less dependent on $\mathrm{pH}$ : as a consequence, 
there is a wide $\mathrm{pH}$ range where $\mathrm{SO}_{4}^{\bullet-}$ is able to oxidize water and $\mathrm{OH}^{-}$to ${ }^{\bullet} \mathrm{OH}$, or to its conjugate base $\mathrm{O}^{\bullet-}$.

Therefore, even if a treatment technique is initially designed to produce $\mathrm{SO}_{4}{ }^{\bullet-}$ as the only reactive species, in most cases the system will contain a mix of ${ }^{\bullet} \mathrm{OH}$ and $\mathrm{SO}_{4}{ }^{\bullet-}$. To explain this, consider the thermodynamics of systems containing $\mathrm{H}_{2} \mathrm{O}+\mathrm{SO}_{4}{ }^{2-}+{ }^{\bullet} \mathrm{OH}+\mathrm{SO}_{4}{ }^{\bullet-}$, which can be described by the following semi-reactions and equilibria [53]:

$$
\begin{gathered}
\mathrm{SO}_{4}^{\bullet-}+\mathrm{e}^{-} \rightarrow \mathrm{SO}_{4}{ }^{2-} \\
\bullet \mathrm{OH}+\mathrm{H}^{+}+\mathrm{e}^{-} \rightarrow \mathrm{H}_{2} \mathrm{O} \\
\bullet \mathrm{OH} \leftrightarrows \mathrm{O}^{\bullet-}+\mathrm{H}^{+} \\
\mathrm{HSO}_{4}{ }^{-} \leftrightarrows \mathrm{H}^{+}+\mathrm{SO}_{4}{ }^{2-}
\end{gathered}
$$

By examining reactions (1)-(4) together, one gets the results shown in Figure 3 as the trends of the reduction potentials of ${ }^{\bullet} \mathrm{OH}$ and $\mathrm{SO}_{4}{ }^{\bullet-}$ as a function of $\mathrm{pH}$. The reported data suggest that a "pure" $\mathrm{SO}_{4}{ }^{\bullet-}$-based system could be obtained only at $\mathrm{pH}<2$, where $\mathrm{SO}_{4}{ }^{\bullet-}$ is unable to oxidize water and, on the contrary, one might have the oxidation of $\mathrm{HSO}_{4}{ }^{-}$by • $\mathrm{OH}$ (which does not apply, however, if one generates $\mathrm{SO}_{4}^{\bullet-}$ from the very start).

$$
\bullet \mathrm{OH}+\mathrm{HSO}_{4}{ }^{-} \rightarrow \mathrm{H}_{2} \mathrm{O}+\mathrm{SO}_{4}^{\bullet-} \quad\left[\mathrm{k}=1.7 \times 10^{6} \mathrm{~L} \mathrm{~mol}^{-1} \mathrm{~s}^{-1}\right]
$$

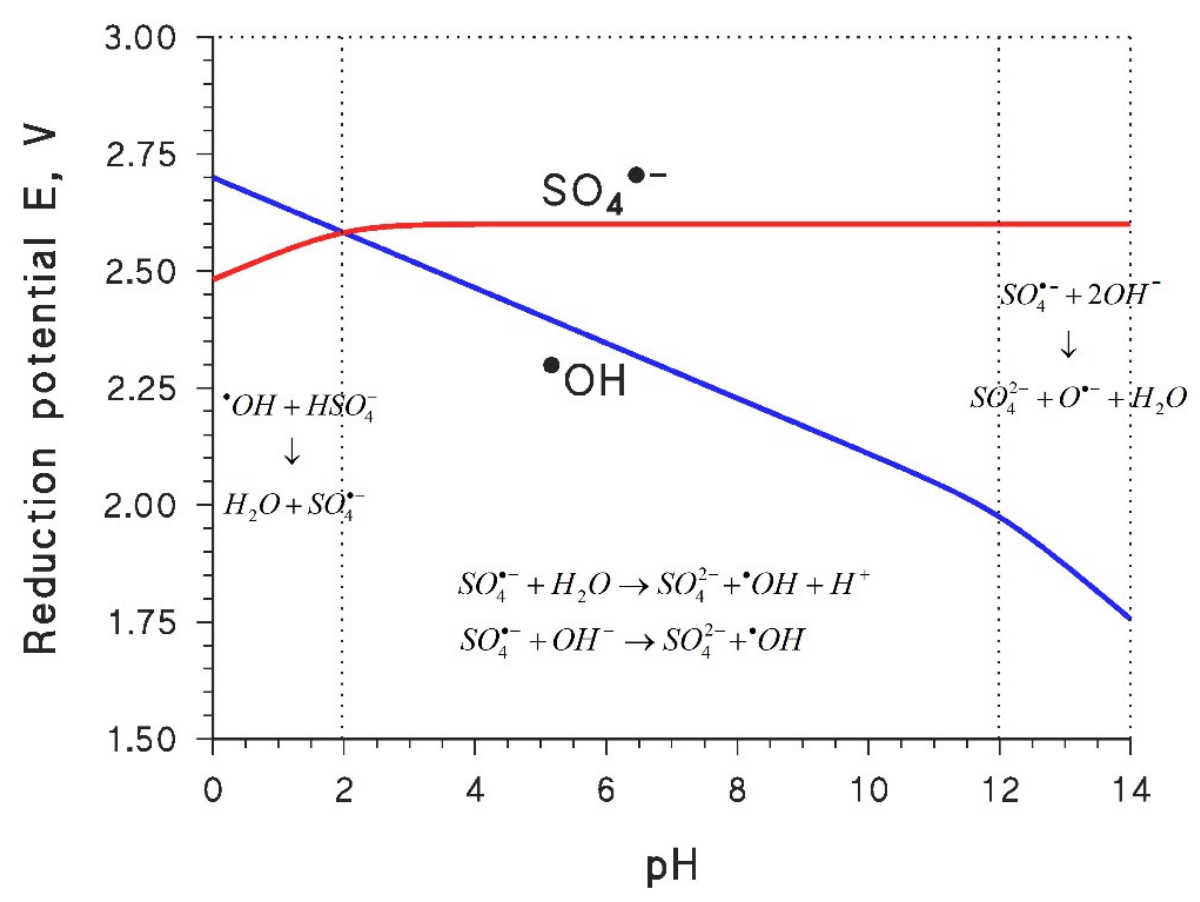

Figure 3. Trends of the reduction potentials of $\mathrm{SO}_{4}{ }^{\bullet-}$ and $\bullet \mathrm{OH}$, as a function of $\mathrm{pH}$ and with standard hydrogen electrode (SHE) as reference electrode. The highlighted $\mathrm{pH}$ values correspond to the $\mathrm{pK}_{\mathrm{a}}{ }^{\prime} \mathrm{s}$

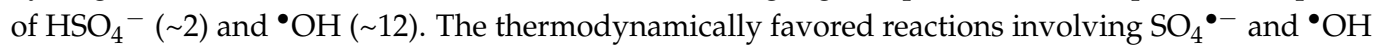
are depicted in the relevant $\mathrm{pH}$ ranges.

The kinetics of reaction (5) [43] is consistent with the thermodynamic insight that is reported in Figure 3. In contrast, at $\mathrm{pH}>2$, which would encompass most conditions found in water treatment, it would be quite difficult to form $\mathrm{SO}_{4}{ }^{\bullet-}$ without also producing ${ }^{\bullet} \mathrm{OH}$ $\left(\right.$ or $\mathrm{O}^{\bullet-}$ ) as a side process. Indeed, in such conditions one gets that $\mathrm{SO}_{4}{ }^{\bullet-}$ is a stronger oxidant than ${ }^{\bullet} \mathrm{OH} / \mathrm{O}^{\bullet-}$, which means that $\mathrm{SO}_{4}{ }^{\bullet-}$ would be able to oxidize $\mathrm{H}_{2} \mathrm{O} / \mathrm{OH}^{-}$to $\bullet \mathrm{OH} / \mathrm{O}^{\bullet-}$.

Of course, apart from thermodynamics, the process kinetics is also very important, and the oxidation of $\mathrm{H}_{2} \mathrm{O}$ by $\mathrm{SO}_{4}{ }^{\bullet-}$ would be in competition with the scavenging of $\mathrm{SO}_{4}^{\bullet-}$ 
itself by other dissolved compounds, which depends by dissolved compound concentration and second-order reaction rate constants with $\mathrm{SO}_{4}{ }^{\bullet-}$. Moreover, because $\mathrm{SO}_{4}{ }^{\bullet-}$ and ${ }^{\bullet} \mathrm{OH}$ often coexist in the same solution, the occurrence and involvement of $\mathrm{SO}_{4}{ }^{\bullet-}$ and /or ${ }^{\bullet} \mathrm{OH}$ in substrate transformation must be assessed on a case-by-case basis. This has often been done in the case of pollutant degradation by ZVI + persulfate, and the studies that have addressed the relative roles of $\mathrm{SO}_{4}{ }^{\bullet-}$ and ${ }^{\bullet} \mathrm{OH}$ will be highlighted whenever relevant in the next section.

\section{Degradation of Pollutants by ZVI-Fenton/Persulfate}

The redox reactivity of ZVI is very interesting because it can be widely modulated depending on the operational conditions. Although it is an electron donor, $\mathrm{ZVI}$ induces oxidant activity in the presence of water, dissolved oxygen, and, most frequently, $\mathrm{H}_{2} \mathrm{O}_{2}$, in which circumstances it can trigger the formation of the strong oxidant ${ }^{\bullet} \mathrm{OH}[5,10]$. By exploiting the reductive and/or oxidative capabilities of ZVI alone, it has been possible to use it for the removal of anions [54,55] as a reductant, but also for the treatment of further contaminants such as heavy metals [56,57], dyes [58], and halogenated organic compounds [5,56], where the reducing and oxidizing characters of ZVI have been exploited. The removal of pollutants by ZVI is neither a purely physical adsorption process, nor a purely chemical/electrochemical process. It includes a complex mixture of different pathways like dissolution, adsorption, redox reaction, and precipitation, which happen simultaneously or in a number of steps on the iron surface.

In particular, the mixture of $\mathrm{ZVI}$ with persulfate is able to trigger a series of reactions (6)-(10) with generation of reactive radicals $\left({ }^{\bullet} \mathrm{OH}, \mathrm{SO}_{4}{ }^{\bullet-}\right)$, which can be extensively exploited for the decontamination of wastewater $[59,60]$.

$$
\begin{gathered}
\mathrm{Fe}^{0}+2 \mathrm{H}_{2} \mathrm{O} \rightarrow \mathrm{Fe}^{2+}+2 \mathrm{OH}^{-}+\mathrm{H}_{2} \\
\mathrm{Fe}^{2+}+\mathrm{S}_{2} \mathrm{O}_{8}{ }^{2-} \rightarrow \mathrm{Fe}^{3+}+\mathrm{SO}_{4}{ }^{2-}+\mathrm{SO}_{4}{ }^{\bullet-} \\
\mathrm{Fe}^{0}+2 \mathrm{Fe}^{3+} \rightarrow 3 \mathrm{Fe}^{2+} \\
\mathrm{Fe}^{2+}+\mathrm{H}_{2} \mathrm{O}_{2} \rightarrow \mathrm{Fe}^{3+}+{ }^{\bullet} \mathrm{OH}+\mathrm{OH}^{-} \\
\mathrm{SO}_{4}{ }^{--}+\mathrm{H}_{2} \mathrm{O} \rightarrow \mathrm{SO}_{4}{ }^{2-}+\cdot \mathrm{OH}+\mathrm{H}^{+}
\end{gathered}
$$

Note that reactions (7) and (9) describe the Fenton and Fenton-like production of oxidizing species, the interconversion of which is depicted by reaction (10). Moreover, the reactions of iron species with dissolved molecular oxygen (here not shown) can produce Fenton reagents as well. The cycling of Fe species having different redox states is shown by reactions (6)-(9).

Nanoscale ZVI (nZVI) is often used as $\mathrm{Fe}^{0}$ form in these processes [30,59], because the favorable surface-to-volume ratio of ZVI nanoparticles enhances their reactivity [22]. The other side of the coin is the fact that nZVI undergoes fast surface oxidation that may hamper its reuse [61]. However, at least in the case of $\mathrm{ZVI} / \mathrm{H}_{2} \mathrm{O}_{2}$, it has been found that passivated nZVI (i.e., nZVI covered with a layer of Fe oxides) retains significant Fenton reactivity that would be an advantage in the case of possible reuse [62]. Furthermore, again in the framework of $\mathrm{ZVI} / \mathrm{H}_{2} \mathrm{O}_{2}$ it has been shown that the nZVI doses needed to degrade contaminants are quite low and do not affect much the process economics, even in the case of difficult reuse [63]. It is clear that the above findings reported for $\mathrm{ZVI} / \mathrm{H}_{2} \mathrm{O}_{2}$ need confirmation in the case of ZVI/PS. Moreover, a family of promising composite materials based on amorphous $\mathrm{Fe}$ (metallic glasses) has also been developed recently, with the ability to activate $\mathrm{H}_{2} \mathrm{O}_{2}, \mathrm{PS}$, and $\mathrm{SO}_{5}{ }^{2-}$ and with an interesting performance as far as reuse is concerned [64-67].

To make some examples of the application of ZVI/PS to decontamination processes, Deng et al. [68] have chosen acetaminophen (APAP) as representative pollutant for pharmaceuticalindustry wastewater, applying the iron/persulfate ( $\left.\mathrm{Fe}^{0} / \mathrm{PS}\right)$ Fenton-like process to APAP degradation. They studied the effects of $\mathrm{pH}$, iron dosage, and addition of chelating agents 
over the $\mathrm{Fe}^{0} / \mathrm{PS}$ system. The highest efficiency ( $\left.93 \%\right)$ was achieved with a 1:1 molar ratio between iron and PS. Effective degradation ( $>90 \%$ ) was observed in a broad pH range (3-8.5), while the presence of $\mathrm{Fe}^{0}$ was assumed to be important for the regeneration of $\mathrm{Fe}^{2+}$ by reaction (8) with $\mathrm{Fe}^{3+}$. Both $\mathrm{SO}_{4}{ }^{\bullet-}$ and ${ }^{\bullet} \mathrm{OH}$ were found to be involved in APAP degradation. Herein, the production and interconversion of radicals have been observed. Zhang et al. [59] have synthesized nanosized ZVI (nZVI) to carry out nZVI/PS degradation of Norfloxacin (NOR). The highest degradation efficiency $\left(93.8 \%\right.$ ) of $100 \mathrm{mg} \mathrm{L}^{-1} \mathrm{NOR}$ was achieved with $100 \mathrm{mg} \mathrm{L}^{-1} \mathrm{nZVI}, 12 \mathrm{mM}$ PS and $\mathrm{pH}$ 7.0. The reaction followed the pseudo-first-order kinetic model. From both quenching experiments and EPR analysis it was derived that both $\mathrm{SO}_{4}{ }^{\bullet-}$ and ${ }^{\bullet} \mathrm{OH}$ were involved in NOR degradation, but ${ }^{\bullet} \mathrm{OH}$ played the main role. It was found an optimum nZVI dosage for degradation [59], above which it can be assumed that nZVI would scavenge ${ }^{\bullet} \mathrm{OH}$ to a significant extent [69]. Moreover, high temperature and PS concentration favored the degradation process. Jiang et al. suggested that $\mathrm{Fe}^{0}$ is an efficient source of $\mathrm{Fe}^{2+}$ to activate persulfate $\left(\mathrm{S}_{2} \mathrm{O}_{8}{ }^{2-}\right)$ to $\mathrm{SO}_{4}{ }^{\bullet-}$ for the degradation of bisphenol A (BPA). High initial persulfate or $\mathrm{Fe}^{0}$ concentration decreased the BPA removal, but the degradation efficiency increased from 49 to $97 \%$ with sequential additions [70]. The use of sequential additions of reagents, which are then consumed in the Fenton reaction, is useful to prevent the reagents to reach excessive concentration values at any time point, differently from a large, single initial addition. Indeed, excess reagents may be detrimental to degradation because they scavenge reactive species $\left({ }^{\bullet} \mathrm{OH}\right.$ and $/$ or $\mathrm{SO}_{4}^{\bullet-}$ ) [69]. The $\mathrm{pH}$ where the system works at its best efficiency is $\mathrm{pH} 3$, but maintaining this $\mathrm{pH}$ value is problematic due to the high cost of the needed reagents.

It is quite clear from the above discussion that $\mathrm{pH}$ and reagent dosage have significant effects over the degradation efficiency. The following section describes the effect of $\mathrm{pH}$ over the ZVI/PS process, including the formation of different reactive radicals.

\subsection{Effect of $p H$}

Apart from the intrinsic properties of iron, some other operational parameters affect the performance of ZVI-Fenton, including $\mathrm{pH}$, iron dosage, dissolved oxygen, iron pretreatment, temperature, and $\mathrm{PS} / \mathrm{Fe}^{0}$ ratio $[5,50,71]$. Among all of the above factors, $\mathrm{pH}$ plays a crucial role because it affects both the rate of generation of radicals and the speciation of many contaminants, thereby highly affecting the degradation performance.

Wu et al. [72] have observed higher degradation of sulfamethazine in acidic compared to basic media. In particular, in the presence of PS the degradation efficiency decreased from $91 \%$ to $34 \%$ as the initial $\mathrm{pH}$ was increased from 5 to 10 . Degradation was significantly improved (95-98\%) in the whole $\mathrm{pH}$ range upon addition of $\mathrm{H}_{2} \mathrm{O}_{2}$, but it was still slightly higher at $\mathrm{pH}$ 5. Overall, these data suggest that acidic $\mathrm{pH}$ may be favorable to the formation of oxidizing species such as ${ }^{\bullet} \mathrm{OH}$ and $\mathrm{SO}_{4}{ }^{\bullet-}$.

As similar decrease in degradation efficiency with increasing $\mathrm{pH}(3-11)$ has been reported by Zhang et al. [73] who used ultrasound-nZVI/PS to degrade chloramphenicol (CAP). The effect of $\mathrm{pH}$ was attributed to several factors, including (i) precipitation of Fe at alkaline $\mathrm{pH}$ and passivation of the ZVI surface, which gets covered by a layer of Fe (hydr)oxides that hinder CAP decomposition; (ii) lower dissolution of ZVI at higher $\mathrm{pH}$, which reduces the availability of $\mathrm{Fe}^{2+}$ that is required to activate PS; and (iii) scavenging of $\mathrm{SO}_{4}{ }^{\bullet-}$ by $\mathrm{H}_{2} \mathrm{O}$ and hydroxyl ions at basic $\mathrm{pH}$. However, the replacement of $\mathrm{SO}_{4}^{\bullet-}$ by ${ }^{\bullet} \mathrm{OH}$ as reactive species is not always detrimental to degradation: the effect depends on substrate, operational conditions, and the possible occurrence of interfering agents, thus it cannot be generalized to all circumstances. Overall, $\mathrm{SO}_{4}{ }^{\bullet-}$ was shown to play a more important role than ${ }^{\bullet} \mathrm{OH}$ in the degradation of CAP in the studied system [73]. The elevated performance of ZVI/PS at acidic $\mathrm{pH}$ explains why Diao et al. used this technique for the treatment of acid mine drainage water, to achieve the removal of atrazine (ATZ) [30]. Maximum ATZ removal (84\%) was observed at $\mathrm{pH} 4$ and both radicals $\left(\mathrm{SO}_{4}{ }^{\bullet-}\right.$, $\left.{ }^{\bullet} \mathrm{OH}\right)$ were involved, with a dominant role played by $\mathrm{SO}_{4}{ }^{\bullet-}$. Du et al. have carried out degradation of Acid orange 7 (AO7) with granular red mud reinforced by ZVI and 
persulfate (Fe@GRM/PS) [74]. The study covered a very broad pH range (1-13), and the degradation efficiency was consistently decreased from $94 \%$ down to $18 \%$ as the $\mathrm{pH}$ increased. There is also evidence that adsorption of AO7 on the surface of Fe@GRM played an important role in the degradation process.

Different quenching chemicals have been used to mask the effect of radicals or to capture them. For instance, 5,5-dimethyl-1-pyrroline N-oxide (DMPO) was utilized to capture $\mathrm{SO}_{4}{ }^{\bullet-}$ and ${ }^{\bullet} \mathrm{OH}$ in case of fenitrothion [75], methanol for sulfadiazine [76], $\mathrm{NaNO}_{2}$ for acetaminophen [68], and ethanol for diuron [77].

In summary, it is indicated from the above discussion that the process triggered by $\mathrm{ZVI} / \mathrm{PS}$ has an important dependence on $\mathrm{pH}$. Results from the above and additional studies are reported in Table 1, which highlights both the effect of $\mathrm{pH}$ and the role of the reactive radical species $\left(\mathrm{SO}_{4}{ }^{\bullet-}\right.$ and $\left./{ }^{\circ} \mathrm{OH}\right)$ in substrate degradation. The table shows that acidic conditions are favorable to the Fenton-like degradation in the vast majority of cases, with only few exceptions. Precipitation of Fe(III) (hydr)oxides with increasing pH, and enhanced dissolution of ZVI with higher occurrence of $\mathrm{Fe}^{2+}$ in acidic conditions, are the most likely general explanations for the observed $\mathrm{pH}$ effect.

Table 1. Summary of the effect of $\mathrm{pH}$ along with generation of respective radicals with different pollutants. Note that Psi $=$ porous silicate.

\begin{tabular}{|c|c|c|c|c|}
\hline Pollutants & Experimental Conditions & pH (\% Degradation) & Main Reactive Species & Reference \\
\hline Acetaminophen & $\begin{array}{l}\text { Pollutant concentration: } 0.066 \mathrm{mM} \\
\text { ZVI: } 0.1-1 \mathrm{~g} / \mathrm{L} \\
\text { PS: } 0.4 \mathrm{mM}\end{array}$ & $\begin{array}{c}3-8.5(>90 \%) \\
1.5(49.51 \%) \\
10.0(16.57 \%)\end{array}$ & $\mathrm{SO}_{4}^{\bullet-}, \bullet \mathrm{OH}$ & [68] \\
\hline Acid Orange 7 & $\begin{array}{l}\text { Pollutant concentration: } 200 \mathrm{mg}^{-1} \mathrm{~g} \\
\text { Iron source: } 0.1-1.4 \mathrm{~g} / \mathrm{L} \\
\text { PS: } 5-500 \mathrm{mM}\end{array}$ & $\begin{array}{c}1.0(93.95 \%) \\
3.0(93.22 \%) \\
5.0(91.34 \%) \\
7.0(66.25 \%) \\
9.0(52.52 \%) \\
11.0(21.62 \%) \\
13.0(18.26 \%)\end{array}$ & $\mathrm{SO}_{4}{ }^{\bullet-}$ & [74] \\
\hline Anisole & $\begin{array}{c}\text { Pollutant concentration: } 1 \mathrm{mM} \\
\text { PS: } 0.25-0.5 \mathrm{M}\end{array}$ & $\begin{array}{c}11.0(40 \%) \\
12.0(>99 \%)\end{array}$ & $\mathrm{SO}_{4}^{\bullet-}, \bullet \mathrm{OH}$ & [47] \\
\hline Arsenic & $\begin{array}{c}\text { Pollutant concentration: } 50 \mu \mathrm{M} \\
\text { ZVI: } 0.1-0.4 \mathrm{~g} / \mathrm{L} \\
\text { PS: } 0.5-10 \mathrm{mM}\end{array}$ & $\begin{array}{c}3.0(>99 \%) \\
5.0(98 \%) \\
7.0(96 \%) \\
9.0(60 \%) \\
11.0(51 \%)\end{array}$ & $\mathrm{SO}_{4}{ }^{\bullet-}, \bullet \mathrm{OH}$ & [36] \\
\hline Atrazine & $\begin{array}{c}\text { Pollutant concentration: } 2.5-15 \\
\mathrm{mg} / \mathrm{L} \\
\text { ZVI: } 0.25-1 \mathrm{~g} / \mathrm{L} \\
\text { PS: } 0.25-0.50 \mathrm{mM}\end{array}$ & $4.0(84 \%)$ & $\mathrm{SO}_{4}^{\bullet-}(84 \%), \bullet \mathrm{OH}$ & [30] \\
\hline Atrazine & $\begin{array}{c}\text { Pollutant concentration: } 25 \mathrm{mg} / \mathrm{L} \\
\text { ZVI/BC: } 175 \mathrm{mg} / \mathrm{L} \\
\text { PS: } 2 \mathrm{mM}\end{array}$ & $3.0(83.77 \%)$ & $\mathrm{SO}_{4}{ }^{\bullet-}, \bullet \mathrm{OH}$ & [78] \\
\hline Chloramphenicol & $\begin{array}{c}\text { Pollutant concentration: } 0.05 \mathrm{M} \\
\text { ZVI: } 0.12-4 \mathrm{mM} \\
\text { PS: } 0.25-3 \mathrm{mM}\end{array}$ & $\begin{array}{c}3.0(95.1) \\
5.0(94.3) \\
7.0(93.4) \\
8.5(93.2) \\
10.0(92.5)\end{array}$ & $\mathrm{SO}_{4}{ }^{\bullet-}, \bullet \mathrm{OH}($ Dominant $)$ & [79] \\
\hline $\begin{array}{c}\text { Diuron } \\
\text { (3-(3,4-Dichlorophenyl)- } \\
\text { 1,1-Dimethylurea) }\end{array}$ & $\begin{array}{c}\text { Pollutant concentration: } 0.05 \mathrm{M} \\
\text { ZVI: } 0.05-1 \mathrm{mM} \\
\text { PS: } 0.5 \mathrm{M}\end{array}$ & $\begin{array}{c}3.0(82 \%) \\
7.0(65 \%) \\
9.0 \text { (No Degradation) } \\
11.0 \text { (No Degradation) }\end{array}$ & $\mathrm{SO}_{4}{ }^{\bullet-}($ Dominant $), \bullet \mathrm{OH}$ & [77] \\
\hline Fenitrothion & 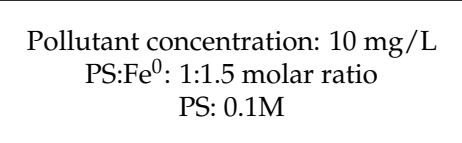 & $\begin{array}{l}3.0 \\
5.0 \\
7.0 \\
9.0\end{array}$ & $\mathrm{SO}_{4}^{\bullet-}$ & [75] \\
\hline
\end{tabular}


Table 1. Cont.

\begin{tabular}{|c|c|c|c|c|}
\hline Pollutants & Experimental Conditions & pH (\% Degradation) & Main Reactive Species & Reference \\
\hline Naproxen & $\begin{array}{c}\text { Pollutant concentration: } 25 \mu \mathrm{M} \\
\text { ZVI: } 0.25-1.50 \mathrm{mM} \\
\text { PS: } 0.1-0.5 \mathrm{mM}\end{array}$ & $\begin{array}{l}3.0 \\
5.0 \\
7.0 \\
9.0\end{array}$ & $\mathrm{SO}_{4}{ }^{\bullet-}, \bullet \mathrm{OH}$ & [80] \\
\hline Nitrobenzene & $\begin{array}{c}\text { Pollutant concentration: } 1 \mathrm{mM} \\
\text { PS: } 0.25-0.5 \mathrm{M}\end{array}$ & $\begin{array}{c}11.0(40 \%) \\
12.0(>60 \%)\end{array}$ & $\bullet \mathrm{OH}$ & [47] \\
\hline Nitrobenzene & $\begin{array}{c}\text { Pollutant concentration: } 200 \mathrm{mg} / \mathrm{L} \\
\text { ZVI: } 0.75 \mathrm{~g} / \mathrm{L} \\
\mathrm{Na}_{2} \mathrm{~S}_{2} \mathrm{O}_{8}: 26.8 \mathrm{mM}\end{array}$ & $5.0(100 \%)$ & $\mathrm{SO}_{4}^{\bullet-}, \bullet \mathrm{OH}$ & [81] \\
\hline Norfloxacin & $\begin{array}{c}\text { Pollutant concentration: } 100 \mathrm{mg} / \mathrm{L} \\
\text { ZVI: } 0.075-0.3 \mathrm{~g} / \mathrm{L} \\
\text { PS: } 3 \mathrm{mM}\end{array}$ & $\begin{array}{c}3.0(>90 \%) \\
4.5(>90 \%) \\
7.0(93.8 \%) \\
9.5(89.9 \%) \\
11.0(80.8 \%) \\
\end{array}$ & $\mathrm{SO}_{4}{ }^{\bullet-}, \bullet \mathrm{OH}$ & [59] \\
\hline Orange G & $\begin{array}{c}\text { Pollutant concentration: } 100 \mathrm{mg} / \mathrm{L} \\
\text { Psi@ZVI: } 0.2 \mathrm{~g} / \mathrm{L} \\
\text { PS: } 16 \mathrm{mM}\end{array}$ & $\begin{array}{c}3.0(99.66 \%) \\
5.0(98.34 \%) \\
6.9(98.93 \%) \\
8.0(98.89 \%) \\
10.0(96.76 \%)\end{array}$ & $\mathrm{SO}_{4}{ }^{\bullet-}, \bullet \mathrm{OH}$ & [82] \\
\hline Propranolol & $\begin{array}{c}\text { Pollutant concentration: } 40 \mu \mathrm{M} \\
\text { ZVI: } 0.15 \mathrm{~g} / \mathrm{L} \\
\text { PS: } 1 \mathrm{mM}\end{array}$ & $\begin{array}{c}3.0(97 \%) \\
4.5(94.2 \%) \\
7.0(89.4 \%) \\
11.0(35.4 \%) \\
\end{array}$ & $\mathrm{SO}_{4}^{\bullet-}, \bullet \mathrm{OH}$ & [83] \\
\hline$p$-Chloroaniline & $\begin{array}{c}\text { Pollutant concentration: } 0.05 \mathrm{mM} \\
\text { ZVI: } 0.70 \mathrm{~g} / \mathrm{L} \\
\text { PS: } 2.5 \mathrm{mM}\end{array}$ & $\begin{array}{c}4.0(100 \%) \\
9.0(43.59 \%) \\
11.0(41.52 \%)\end{array}$ & $\mathrm{SO}_{4}{ }^{\bullet-}, \bullet \mathrm{OH}$ & [84] \\
\hline $\begin{array}{l}\text { 1-(6-Chloro-3- } \\
\text { Pyridylmethyl) } \\
\text {-N-Nitro-Imidazolidin-2- } \\
\text { Ylideneamine }\end{array}$ & $\begin{array}{c}\text { Pollutant concentration: } 30 \mathrm{ppm} \\
\text { ZVI: } 0.5-3 \mathrm{~g} / \mathrm{L} \\
\text { PS: } 2.5-15 \mathrm{mM}\end{array}$ & $7.0(88 \%)$ & $\mathrm{SO}_{4}{ }^{\bullet-}, \bullet \mathrm{OH}$ & [85] \\
\hline Sulfadiazine & $\begin{array}{c}\text { Pollutant concentration: } 20 \mathrm{mg} / \mathrm{L} \\
\text { ZVI: } 0.92 \mathrm{mM} \\
\text { PS: } 1.84 \mathrm{mM}\end{array}$ & $\begin{array}{c}3.0-7.0(95.7-98.4 \%) \\
10.0(35.7 \%)\end{array}$ & $\mathrm{SO}_{4}{ }^{\bullet-}$ & [76] \\
\hline Reactive Blue 19 & $\begin{array}{c}\text { Pollutant concentration: } 0.3 \mathrm{mM} \\
\text { ZVI: } 0.8 \mathrm{~g} / \mathrm{L} \\
\text { PS: } 10 \mathrm{mM}\end{array}$ & $\begin{array}{l}3.0(99 \%) \\
5.0 \\
7.0 \\
9.0\end{array}$ & $\mathrm{SO}_{4}{ }^{\bullet-}$ & [86] \\
\hline
\end{tabular}

Another issue that is linked to $\mathrm{pH}$ is the fact that oxidation of $\mathrm{H}_{2} \mathrm{O} / \mathrm{OH}^{-}$to ${ }^{\bullet} \mathrm{OH}$ by $\mathrm{SO}_{4}{ }^{\bullet-}$ is favored in neutral to basic solutions as compared to acidic ones, as already discussed in Section 2. The choice of using PS over $\mathrm{H}_{2} \mathrm{O}_{2}$ as Fenton oxidant is usually motivated by the desire to produce $\mathrm{SO}_{4}{ }^{\bullet-}$ instead of ${ }^{\bullet} \mathrm{OH}$ as reactive species (e.g., because of higher $\mathrm{SO}_{4}{ }^{\bullet-}$ selectivity). Therefore, a further argument in favor of operation at acidic $\mathrm{pH}$ is represented by the possibility to obtain a simpler system with only one (or a strongly prevailing) reactive species, $\mathrm{SO}_{4}{ }^{--}$. Indeed, whenever allowed in the framework of water treatment, the operation of $\mathrm{ZVI} / \mathrm{PS}$ at acidic $\mathrm{pH}$ would combine higher Fenton-like reactivity with higher selectivity due to $\mathrm{SO}_{4}{ }^{\bullet-}$.

\subsection{Effect of Inorganic Anions}

\subsubsection{Chloride}

The effect of chloride ions on the ZVI/PS process has been controversial because chloride can induce some contrasting processes in Fenton-like systems. In particular, $\mathrm{Cl}^{-}$can boost the corrosion of $\mathrm{Fe}^{0}$ [87], and it can also scavenge $\mathrm{SO}_{4}{ }^{\bullet-}$ and /or ${ }^{\bullet} \mathrm{OH}$ with generation of reactive chlorine species (RCS) such as $\mathrm{Cl}_{2}{ }^{\bullet-}, \mathrm{Cl}^{\bullet}$, and $\mathrm{Cl}_{2}$ [88]. Note that scavenging of $\mathrm{SO}_{4}{ }^{--}$by $\mathrm{Cl}^{-}$can take place at any $\mathrm{pH}$ value, while net scavenging of ${ }^{\bullet} \mathrm{OH}$ by $\mathrm{Cl}^{-}$occurs only at acidic $\mathrm{pH}[43,44]$. Depending on the conditions, the overall effect of chloride can be either an enhancement or an inhibition of pollutant degradation. To 
account for inhibition, it has been invoked the scavenging by chloride of strong oxidizing species $\left(\mathrm{SO}_{4}{ }^{\bullet-}, \bullet \mathrm{OH}\right)$ that are replaced by less reactive RCS such as $\mathrm{Cl}_{2}{ }^{\bullet-}[89]$.

$$
\begin{array}{cc}
\mathrm{SO}_{4}^{\bullet-}+\mathrm{Cl}^{-} \rightarrow \mathrm{Cl}^{\bullet}+\mathrm{SO}_{4}{ }^{2-} & \mathrm{k}=2.7 \times 10^{8} \mathrm{M}^{-1} \mathrm{~s}^{-1} \\
\mathrm{Cl}^{\bullet}+\mathrm{Cl}^{-} \rightarrow \mathrm{Cl}_{2}^{\bullet-} \quad \mathrm{k}=4.4 \times 10^{8} \mathrm{M}^{-1} \mathrm{~s}^{-1} \\
\mathrm{Cl}^{\bullet}+\mathrm{H}_{2} \mathrm{O} \rightarrow \mathrm{HOCl}^{\bullet-}+\mathrm{H}^{+} & \mathrm{k}=2.5 \times 10^{5} \mathrm{~s}^{-1} \\
\mathrm{Cl}_{2}^{\bullet-}+\mathrm{Cl}_{2}^{\bullet-} \rightarrow \mathrm{Cl}_{2}+2 \mathrm{Cl}^{-} & \mathrm{k}=2.1 \times 10^{9} \mathrm{M}^{-1} \mathrm{~s}^{-1} \\
\mathrm{HOCl}^{\bullet-} \rightarrow \bullet{ }^{\bullet} \mathrm{OH}+\mathrm{Cl}^{-} & \mathrm{k}=6.1 \times 10^{9} \mathrm{~s}^{-1}
\end{array}
$$

Interestingly, there is evidence that the Fenton-like systems based on ZVI/PS have an improvement in performance in the presence of chloride when the concentration of the latter is low (around $1 \mathrm{mM}$ ), while degradation worsens considerably at high chloride $(\geq 10 \mathrm{mM})$. A reasonable explanation is that $\mathrm{Cl}^{-}$at low concentration activates $\mathrm{ZVI}$ corrosion and stimulates the activation of $\mathrm{PS}$ by $\mathrm{Fe}^{2+}$ [21]. On the other hand, elevated $\mathrm{Cl}^{-}$concentration would rather produce scavenging of $\mathrm{SO}_{4}{ }^{\bullet-}$ (and/or ${ }^{\bullet} \mathrm{OH}$ ) [90], replaced by less reactive $\mathrm{RCS}\left(\mathrm{Cl}_{2}{ }^{--}, \mathrm{Cl}^{\bullet}, \mathrm{Cl}_{2}\right)$.

Coherently, Kim et al. have reported that different concentrations of chloride have different effects on ZVI/PS [89]. They concluded that there is an optimum value of $\left[\mathrm{Cl}^{-}\right]$ for which degradation is most efficient $\left(170 \mathrm{mM} \mathrm{Cl}^{-}\right.$, equivalent to $\sim 1 \%$ dissolved salts that is in the range of brackish waters). Indeed, based on the obtained results, it was inferred that pollutant degradation by ZVI/PS might be more efficient in brackish waters than in either freshwater, or more saline waters $\left(600 \mathrm{~m} \mathrm{M} \mathrm{Cl}^{-}\right.$, equivalent to $\sim 3.5 \%$ dissolved salts as found in seawater).

Chlorinated by-products can be formed during the process and they may be toxic. Although this issue has not been explored much so far, a few intermediate chlorinated by-products have been detected as reported here in Table 2. The formation of chlorinated by-products is quite likely in the presence of RCS and of electron-rich substrates [91]. Indeed, $\mathrm{SO}_{4}{ }^{--}$can oxidize $\mathrm{Cl}^{-}$to produce the chlorinating agents $\mathrm{Cl}^{\bullet}, \mathrm{Cl}_{2}$ upon radical condensation, and $\mathrm{Cl}_{2}{ }^{\bullet-}$ upon reaction between $\mathrm{Cl}^{\bullet}$ and $\mathrm{Cl}^{-}$[44]. The table also

\begin{tabular}{|c|c|c|c|c|}
\hline Pollutant & $\mathrm{pH}$ & $\begin{array}{l}\text { Effect of Chloride } \\
\quad(+v e /-v e /=)\end{array}$ & Chlorinated by-Products & Reference \\
\hline Acid Orange 7 & $3-11$ & $\begin{array}{l}\text { +ve }(1-100 \mathrm{mM}) \\
\text { - ve }(>100 \mathrm{mM})\end{array}$ & $\begin{array}{l}\text { 5-Chloroisobenzofuran-1,3-Dione, 1-Chloro- } \\
\text { 2-(Dimethoxymethyl)Benzene, } \\
\text { 1-(3-Chlorophenyl) Propan-1-One } \\
\text { 2-Chlorobenzaldehyde }\end{array}$ & [92] \\
\hline Bisphenol A & $6-8$ & $+\mathrm{ve}$ & Trichloronitromethane & [93] \\
\hline Carbamazepine & $6-8$ & +ve & $\begin{array}{l}\text { Trichloromethane, Trichloroacetonitrile, } \\
\text { Trichloronitromethane }\end{array}$ & [94] \\
\hline Chloramphenicol & $5-8$ & Absence of Chloride & Dichloroacetamide & [95] \\
\hline Chloramphenicol & $3-9$ & +ve $(<1 \mathrm{mM})$ & & [79] \\
\hline 4-Chlorophenol & $2-7$ & $\begin{array}{l}\text { +ve }(1 \mathrm{mM}) \\
\text { - ve }(>5 \mathrm{mM})\end{array}$ & & [21] \\
\hline 2-Chlorophenol & 7.9 & Absence of Chloride & $\begin{array}{c}\text { 2-Chloro-4- } \\
\text { Nitrophenol (2C4NP), } \\
\text { 2-Chloro-6-Nitrophenol (2C6NP) }\end{array}$ & [96] \\
\hline
\end{tabular}
reports whether $\mathrm{Cl}^{-}$enhanced or suppressed the degradation of pollutants at the chloride concentrations used in each relevant study.

Table 2. Effect of chloride ion over pollutant degradation (+ve: Positive effect; - ve: negative effect), and formation of chlorinated by-products. 
Table 2. Cont.

\begin{tabular}{|c|c|c|c|c|}
\hline Pollutant & $\mathrm{pH}$ & $\begin{array}{c}\text { Effect of Chloride } \\
(+\mathrm{ve} /-\mathrm{ve} /=)\end{array}$ & Chlorinated by-Products & Reference \\
\hline $\begin{array}{l}\text { (2-Chloro- } N-2,6 \text {-Diethylphenyl- } \\
N \text {-(Methoxymethyl)Acetamide }\end{array}$ & $7.61-8.76$ & $+\mathrm{ve}$ & $\begin{array}{c}\text { Trichloromethane, } \\
\text { 1,1,3-Trichloro-2-Propanone } \\
\text { 1,3-Dichloro-2-Propanone }\end{array}$ & [97] \\
\hline 2,4-Di-Tert-Butylphenol & $7-8$ & $+\mathrm{ve}$ & Trichloromethane & [98] \\
\hline Perchloroethylene & 7 & No Effect up to $28 \mathrm{mM}$ & & [99] \\
\hline Propanolol & & - ve $(\geq 5 \mathrm{mM})$ & & [83] \\
\hline Phenol & 2.5 & $\begin{array}{l}\text { +ve }(25-200 \mathrm{mM}) \\
\text {-ve }(>400 \mathrm{mM})\end{array}$ & & [89] \\
\hline Phenol & $3.9-4.4$ & No Effect & & [100] \\
\hline Rhodamine B & $2-12$ & +ve up to $50 \mathrm{mM} \mathrm{Cl}^{-}$ & & [101] \\
\hline Sulfadiazine & 4.0 & + ve up to $\leq 10 \mathrm{mM}$ & & [102] \\
\hline Sulfamethoxazole & & $+\mathrm{ve}$ & & [103] \\
\hline
\end{tabular}

\subsubsection{Nitrate/Nitrite}

The effect of nitrate and nitrite ions over Fenton systems based on hydroxyl and sulfate radicals has not been explored much. However, in the presence of nitrate and especially nitrite, one can expect scavenging of sulfate radicals as shown in equations $(16,17)$, as well as of ${ }^{\bullet} \mathrm{OH}$.

$$
\begin{aligned}
& \mathrm{NO}_{3}{ }^{-}+\mathrm{SO}_{4}{ }^{--} \rightarrow \mathrm{NO}_{3}{ }^{\bullet}+\mathrm{SO}_{4}{ }^{2-} \\
& \mathrm{NO}_{2}{ }^{-}+\mathrm{SO}_{4}{ }^{\bullet-} \rightarrow \mathrm{NO}_{2}{ }^{\bullet}+\mathrm{SO}_{4}{ }^{2-}
\end{aligned}
$$

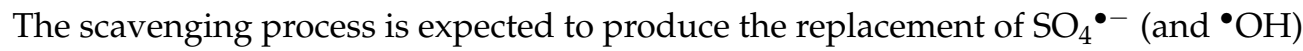
with less reactive radicals $\left(\mathrm{NO}_{3}{ }^{\bullet}\right.$ and especially $\left.\mathrm{NO}_{2}{ }^{\bullet}\right)$, which should inhibit Fenton degradation, but the actual outcome depends on the conditions and the target substrate. The nitrate radical would regenerate nitrate by reacting, thus nitrate is not expected to change in concentration due to this process. Conversely, nitrite is oxidized to nitrate.

For instance, Guo et al. have recently reported the effect of nitrate on the decontamination of sulfadiazine by ZVI/PS [102]. For reasons that are still to be explained, a small amount of nitrate $(<10 \mathrm{mM})$ was found to enhance the removal efficiency. In contrast, the removal of sulfadiazine was inhibited in the presence of higher nitrate concentrations (10-50 mM). The latter effect was attributed to a scavenging process (reaction (16)), combined to the lower reactivity of $\mathrm{NO}_{3}{ }^{\bullet}$ when compared with $\mathrm{SO}_{4}{ }^{\bullet-}[44,53]$.

Inhibition of pollutant degradation by $\mathrm{PS} / \mathrm{SO}_{4}{ }^{\circ-}$ has also been observed in the presence of nitrite at relatively high concentration values $(>100 \mu \mathrm{M})$ [96]. The oxidation of $\mathrm{NO}_{2}{ }^{-}$to $\mathrm{NO}_{2}{ }^{\bullet}$ by $\mathrm{SO}_{4}{ }^{--}$(reaction 17) is expected to induce a double effect: (i) inhibition of pollutant degradation, because $\mathrm{NO}_{2}{ }^{\bullet}$ is considerably less reactive than $\mathrm{SO}_{4}{ }^{\bullet-}$ (and than $\mathrm{NO}_{3}{ }^{\bullet}$ as well: indeed, nitrite has the potential to inhibit degradation at a higher extent than nitrate if concentrations are comparable) [44,53], and (ii) formation of nitrated by-products, because of the activity of $\mathrm{NO}_{2} \bullet$ as nitrating agent. Coherently, the degradation of 2-chlorophenol in the presence of $\mathrm{SO}_{4}{ }^{\bullet-}$ and nitrite has been reported to form different chloronitrophenols, including 2C4NP and 2C6NP [96]. Because these nitro-derivatives that are formed in the process may be toxic, their production should be considered and avoided whenever possible.

To date, only a minority of studies that investigated the effect of nitrate/nitrite on $\mathrm{SO}_{4}{ }^{\bullet-}$-induced degradation has focused on the formation of nitrated by-products. A short summary of the investigated pollutants, the influence of nitrate/nitrite on their degradation and the detected by-products is given in Table 3. 
Table 3. Effect of nitrite/nitrate ion over pollutant degradation.

\begin{tabular}{|c|c|c|c|c|}
\hline Pollutant & $\mathrm{pH}$ & $\begin{array}{c}\text { Effect of } \\
\text { Nitrate/Nitrite }\end{array}$ & Nitro-Derivatives as Byproducts & Reference \\
\hline Bisphenol A & 7.0 & $\begin{array}{l}\mathrm{NO}_{2}^{-} \\
+\mathrm{ve}\end{array}$ & Trichloronitromethane & [93] \\
\hline Chloramphenicol & $3.12-5.4$ & $\begin{array}{c}\mathrm{NO}_{3}^{-} / \mathrm{NO}_{2}^{-} \\
-\mathrm{ve} /-\mathrm{ve}\end{array}$ & & [79] \\
\hline 2-Chlorophenol & 7.0 & $\begin{array}{c}\mathrm{NO}_{3}^{-} \\
+ \text {ve }(50-100 \mu \mathrm{M}) \\
\text {-ve }(>100 \mu \mathrm{M})\end{array}$ & $\begin{array}{c}\text { 2-chloro-4- } \\
\text { nitrophenol (2C4NP), } \\
\text { 2-chloro-6-nitrophenol (2C6NP) }\end{array}$ & [96] \\
\hline $\begin{array}{l}\text { (2-Chloro- } N-2,6-\text { Diethylphenyl- } \\
N \text {-(Methoxymethyl)Acetamide }\end{array}$ & & No effect & & [97] \\
\hline Propanolol & & $\begin{array}{c}\mathrm{NO}_{3}^{-} \\
-\operatorname{ve}(\geq 5 \mathrm{mM})\end{array}$ & & [83] \\
\hline Phenol & $3.9-4.4$ & No effect & & [100] \\
\hline Sulfadiazine & 4.0 & $\begin{array}{l}\mathrm{NO}_{3}^{-}(+\mathrm{ve}<10 \mathrm{mM}) \\
\quad-\text { ve }(10-50 \mathrm{mM})\end{array}$ & & [102] \\
\hline Sulfamethoxazole & & $\begin{array}{l}\mathrm{NO}_{3}^{-} \\
+\mathrm{ve}\end{array}$ & & [103] \\
\hline
\end{tabular}

\subsubsection{Carbonate/Bicarbonate}

Both $\mathrm{HCO}_{3}{ }^{-}$and $\mathrm{CO}_{3}{ }^{2-}$ can scavenge $\mathrm{SO}_{4}{ }^{--}$(as well as ${ }^{\bullet} \mathrm{OH}$ ) and finally produce the carbonate radical, $\mathrm{CO}_{3}{ }^{--}$reactions (18) and (19). Although $\mathrm{CO}_{3}{ }^{\bullet-}$ reacts mainly through electron/hydrogen transfer in a similar way as $\mathrm{SO}_{4}{ }^{\bullet-}, \mathrm{CO}_{3}{ }^{--}$is considerably less reactive than $\mathrm{SO}_{4}{ }^{\bullet-}$ because of the lower one-electron reduction potential $[44,53]$. Because of reactions (18) and (19), one might expect that carbonate and bicarbonate inhibit the degradation of pollutants in the presence of ZVI/PS. This is often observed, but in several circumstances the scenario is more complex because the effects of carbonate and bicarbonate on degradation also depend on their concentration, the $\mathrm{pH}$, and the nature of target pollutant(s).

$$
\begin{gathered}
\mathrm{SO}_{4}{ }^{\bullet-}+\mathrm{CO}_{3}{ }^{2-} \rightarrow \mathrm{CO}_{3}^{\bullet-}+\mathrm{SO}_{4}{ }^{2-} \\
\mathrm{SO}_{4}^{\bullet-}+\mathrm{HCO}_{3}{ }^{-} \rightarrow \mathrm{CO}_{3}{ }^{\bullet-}+\mathrm{H}^{+}+\mathrm{SO}_{4}{ }^{2-}
\end{gathered}
$$

For instance, Bennedsen et al. have investigated the influence of carbonate over PS activation for the degradation of $p$-nitrosodimethylaniline as model pollutant [99]. Notably, in that case the role of $\mathrm{CO}_{3}{ }^{2-}$ could not be assimilated to that of a mere scavenger. A similar, positive effect of $\mathrm{HCO}_{3}{ }^{-} / \mathrm{CO}_{3}{ }^{2-}$ on pollutant degradation by PS activation has been reported by Hayat et al. too [85].

Zhao et al. have studied the effect of water matrices including natural organic matter (NOM) and bicarbonates over the degradation of 2-chlorophenol by PS activation. They found that bicarbonate inhibits degradation due to $\mathrm{SO}_{4}{ }^{--}$scavenging. However, it should also be considered that bicarbonate acts as a buffer for the reaction solutions [96]. Similarly, negative effects of $\mathrm{CO}_{3}{ }^{2-} / \mathrm{HCO}_{3}{ }^{-}$on degradation have been reported in the cases of propranolol and sulfamethoxazole. A short summary of the influence of carbonate/bicarbonate over oxidation by $\mathrm{SO}_{4}{ }^{\bullet-}$ is provided in Table 4 , which also highlights their positive/negative behavior along with the target pollutant under study. 
Table 4. Effect of carbonates/bicarbonates.

\begin{tabular}{|c|c|c|c|}
\hline Pollutant & $\mathrm{pH}$ & Effect of Bi/Carbonate & Reference \\
\hline 2-Chlorophenol & 7.9 & +ve & [96] \\
\hline Imidacloprid & 7.0 & + ve & [85] \\
\hline Phenol & $7.4-11.3$ & + ve & [100] \\
\hline Propranolol & & - ve & [83] \\
\hline$p$-Nitrosodimethylaniline & 12.4 & $\begin{array}{l}\text { +ve }(10-100 \mathrm{mM}) \text { in } \\
\quad \text { alkaline media } \\
\text {-ve in acidic media }\end{array}$ & [99] \\
\hline Sulfamethoxazole & & - ve & [103] \\
\hline Tetrabromobisphenol A & $7.0-8.5$ & - ve & [104] \\
\hline
\end{tabular}

As a final remark, it appears that the effect of $\mathrm{HCO}_{3}{ }^{-}$and $\mathrm{CO}_{3}{ }^{2-}$ over the degradation of pollutants by $\mathrm{SO}_{4}{ }^{--}$needs additional investigation, because it is likely to depend on target pollutant, reaction conditions and other parameters.

\section{Conclusions}

The Fenton-like process based on ZVI and persulfate (ZVI/PS) has the potential to overcome the drawbacks of both homogeneous Fenton (production of sludge, very narrow operational $\mathrm{pH}$ interval) and the ${ }^{\bullet} \mathrm{OH}$-based advanced oxidation processes (non-selective behavior of the hydroxyl radical). However, it is important to consider that it is difficult to obtain a pure $\mathrm{SO}_{4}{ }^{\bullet-}$-based oxidation, because of the ability of $\mathrm{SO}_{4}{ }^{\bullet-}$ itself to oxidize water and $\mathrm{OH}^{-}$to ${ }^{\bullet} \mathrm{OH}$ at $\mathrm{pH}>2$. Therefore, in most cases one will get a mixed process where both ${ }^{\bullet} \mathrm{OH}$ and $\mathrm{SO}_{4}{ }^{\bullet-}$ take part at different degrees in pollutant transformation.

The operational $\mathrm{pH}$ value plays an important role in the degradation efficiency of pollutants by ZVI/PS. Usually the degradation is most efficient at acidic $\mathrm{pH}$, for two main reasons: (i) precipitation of $\mathrm{Fe}(\mathrm{III})$ as the $\mathrm{pH}$ increases, which hampers the recycling of $\mathrm{Fe}$ species and decreases, as a consequence, the production of reactive radicals $\left(\mathrm{SO}_{4}{ }^{-0}\right.$ and - $\mathrm{OH}$ ); (ii) dissolution of ZVI at acidic $\mathrm{pH}$, which provides more Fe species (and especially $\mathrm{Fe}^{2+}$ ) for the Fenton reaction. Despite these limitations, the useful $\mathrm{pH}$ range for degradation by ZVI/PS is usually wider than for homogeneous Fenton. In homogeneous Fenton systems, when $\mathrm{Fe}^{2+}$ is completely oxidized to $\mathrm{Fe}(\mathrm{III})$ by $\mathrm{H}_{2} \mathrm{O}_{2}$ or PS, and $\mathrm{Fe}(\mathrm{III})$ precipitates, reactivity is totally suppressed. In contrast, ZVI might still act as a source of reactive Fe species even at relatively high $\mathrm{pH}$ values, despite a non-negligible loss in reactivity.

Inorganic anions that usually occur in surface waters have the potential to act as scavengers of $\mathrm{SO}_{4}{ }^{\bullet-}$ and/or ${ }^{\bullet} \mathrm{OH}$, producing less reactive radical species and inhibiting degradation as a consequence. However, in particular conditions and with some anions $\left(\mathrm{Cl}^{-}, \mathrm{HCO}_{3}{ }^{-}, \mathrm{CO}_{3}{ }^{2-}\right)$ one might observe enhanced degradation. Therefore, compared to expectations based on radical scavenging, the degradation of pollutants by ZVI/PS might become peculiarly fast in some saline waters. In such cases one should take into account the possible formation of harmful by-products, however. For instance, reactive chlorine species $\left(\mathrm{Cl}_{2}{ }^{\bullet-}, \mathrm{Cl}^{\bullet}\right.$, and $\mathrm{Cl}_{2}$, produced by chloride oxidation) have the potential to form chlorinated compounds, while $\mathrm{NO}_{2} \bullet$ (produced by nitrite oxidation) acts as nitrating agent. The composition of wastewater may be very variable; thus, it is difficult to figure out which anion's effect may be the most significant. However, it appears that nitrite affects degradations by ZVI/PS at quite high concentration values, which would be found in water matrices in only a minority of cases. The tested concentrations of the other ions $\left(\mathrm{NO}_{3}{ }^{-}, \mathrm{Cl}^{-}, \mathrm{HCO}_{3}{ }^{-}\right.$, and $\left.\mathrm{CO}_{3}{ }^{2-}\right)$ are quite comparable with typical water levels, thus the prevailing effect would largely depend on the particular composition of the matrix under treatment. In the case of saline waters, it can be predicted that the effect of chloride would usually be very important. Overall, it can be concluded that the use of the ZVI/PS system 
can be very beneficial to remove aromatic pollutants easily in the presence of interferents such as aliphatic compounds and inorganic ions.

Author Contributions: N.A.: Conception, Design of study, Writing-original draft preparation, editing and interpretation; D.V.: Conception, Design of study, reviewed, revised manuscript and critical revision, supervision; L.R.: visualization; L.C.: revision, editing and visualization; M.C.: Visualization; M.C.B.: Conception, Design of study, reviewed, revised manuscript, critical revision and supervision. All authors have read and agreed to the published version of the manuscript.

Funding: This research received no external funding.

Conflicts of Interest: The authors declare no conflict of interests.

\section{References}

1. Ghanbari, F.; Moradi, M.; Manshouri, M. Textile wastewater decolorization by zero valent iron activated peroxymonosulfate: Compared with zero valent copper. J. Environ. Chem. Eng. 2014, 2, 1846-1851. [CrossRef]

2. Anipsitakis, G.P.; Dionysiou, D.D. Degradation of Organic Contaminants in Water with Sulfate Radicals Generated by the Conjunction of Peroxymonosulfate with Cobalt. Environ. Sci. Technol. 2003, 37, 4790-4797. [CrossRef]

3. Pignatello, J.J.; Oliveros, E.; Mackay, A. Advanced Oxidation Processes for Organic Contaminant Destruction Based on the Fenton Reaction and Related Chemistry. Crit. Rev. Environ. Sci. Technol. 2006, 36, 1-84. [CrossRef]

4. Bokare, A.D.; Choi, W. Review of iron-free Fenton-like systems for activating $\mathrm{H} 2 \mathrm{O} 2$ in advanced oxidation processes. J. Hazard. Mater. 2014, 275, 121-135. [CrossRef] [PubMed]

5. Rezaei, F.; Vione, D. Effect of pH on Zero Valent Iron Performance in Heterogeneous Fenton and Fenton-Like Processes: A Review. Molecules 2018, 23, 3127. [CrossRef]

6. Weng, C.-H.; Lin, Y.-T.; Chang, C.-K.; Liu, N. Decolourization of direct blue 15 by Fenton/ultrasonic process using a zero-valent iron aggregate catalyst. Ultrason. Sonochem. 2013, 20,970-977. [CrossRef] [PubMed]

7. Bogacki, J.; Marcinowski, P.; Zapałowska, E.; Maksymiec, J.; Naumczyk, J. Cosmetic wastewater treatment by the ZVI/ $/ \mathrm{H}_{2} \mathrm{O}_{2}$ process. Environ. Technol. 2016, 38, 2589-2600. [CrossRef]

8. Grčić, I.; Papic, S.; Žižek, K.; Koprivanac, N. Zero-valent iron (ZVI) Fenton oxidation of reactive dye wastewater under UV-C and solar irradiation. Chem. Eng. J. 2012, 195-196, 77-90. [CrossRef]

9. Pouran, S.R.; Raman, A.A.A.; Daud, W.M.A.W. Review on the application of modified iron oxides as heterogeneous catalysts in Fenton reactions. J. Clean. Prod. 2014, 64, 24-35. [CrossRef]

10. Matavos-Aramyan, S.; Moussavi, M. Advances in Fenton and Fenton based oxidation processes for industrial effluent contaminants control-A review. Int. J. Environ. Sci. Nat. Resour. 2017, 2, 1-18.

11. He, J.; Yang, X.; Men, B.; Wang, D. Interfacial mechanisms of heterogeneous Fenton reactions catalyzed by iron-based materials: A review. J. Environ. Sci. 2016, 39, 97-109. [CrossRef] [PubMed]

12. Sun, Y.; Pignatello, J.J. Chemical treatment of pesticide wastes. Evaluation of iron (III) chelates for catalytic hydrogen peroxide oxidation of 2,4-D at circumneutral pH. J. Agric. Food Chem. 1992, 40, 322-327. [CrossRef]

13. Pereira, M.; Oliveira, L.; Murad, E. Iron oxide catalysts: Fenton and Fentonlike reactions-A review. Clay Miner. 2012, 47, $285-302$. [CrossRef]

14. Gumy, D.; Fernandez-Ibañez, P.; Malato, S.; Pulgarin, C.; Enea, O.; Kiwi, J. Supported Fe/C and Fe/Nafion/C catalysts for the photo-Fenton degradation of Orange II under solar irradiation. Catal. Today 2005, 101, 375-382. [CrossRef]

15. Flores, Y.; Flores, R.; Gallegos, A.A. Heterogeneous catalysis in the Fenton-type system reactive black $5 / \mathrm{H}_{2} \mathrm{O}_{2}$. J. Mol. Catal. A Chem. 2008, 281, 184-191. [CrossRef]

16. Kitis, M.; Kaplan, S. Advanced oxidation of natural organic matter using hydrogen peroxide and iron-coated pumice particles. Chemosphere 2007, 68, 1846-1853. [CrossRef] [PubMed]

17. Muthuvel, I.; Swaminathan, M. Highly solar active Fe(III) immobilised alumina for the degradation of Acid Violet 7. Sol. Energy Mater. Sol. Cells 2008, 92, 857-863. [CrossRef]

18. Pramod, L.; Gandhimathi, R.; Lavanya, A.; Ramesh, S.T.; Nidheesh, P.V. Heterogeneous Fenton process coupled with microfiltration for the treatment of water with higher arsenic content. Chem. Eng. Commun. 2019, 207, 1646-1657. [CrossRef]

19. Santos, F.; Lago, F.R.; Yokoyama, L.; Fonseca, F.V. Synthesis and characterization of zero-valent iron nanoparticles supported on SBA-15. J. Mater. Res. Technol. 2017, 6, 178-183. [CrossRef]

20. Fontecha-Camara, M.A.; Álvarez-Merino, M.; Carrasco-Marín, F.; Ramon, M.V.L.; Moreno-Castilla, C. Heterogeneous and homogeneous Fenton processes using activated carbon for the removal of the herbicide amitrole from water. Appl. Catal. B Environ. 2011, 101, 425-430. [CrossRef]

21. Barzegar, G.; Jorfi, S.; Zarezade, V.; Khatebasreh, M.; Mehdipour, F.; Ghanbari, F. 4-Chlorophenol degradation using ultrasound/peroxymonosulfate/nanoscale zero valent iron: Reusability, identification of degradation intermediates and potential application for real wastewater. Chemosphere 2018, 201, 370-379. [CrossRef]

22. Crane, R.; Scott, T. Nanoscale zero-valent iron: Future prospects for an emerging water treatment technology. J. Hazard. Mater. 2012, 211-212, 112-125. [CrossRef] 
23. Lei, C.; Sun, Y.; Tsang, D.C.; Lin, D. Environmental transformations and ecological effects of iron-based nanoparticles. Environ. Pollut. 2018, 232, 10-30. [CrossRef] [PubMed]

24. Raman, C.D.; Kanmani, S. Textile dye degradation using nano zero valent iron: A review. J. Environ. Manag. 2016, 177, 341-355. [CrossRef] [PubMed]

25. Colombo, A.; Dragonetti, C.; Magni, M.; Roberto, D. Degradation of toxic halogenated organic compounds by iron-containing mono-, bi- and tri-metallic particles in water. Inorg. Chim. Acta 2015, 431, 48-60. [CrossRef]

26. Alowitz, M.J.; Scherer, M.M. Kinetics of nitrate, nitrite, and Cr (VI) reduction by iron metal. Environ. Sci. Technol. 2002, 36, 299-306. [CrossRef] [PubMed]

27. Li, X.-Q.; Elliott, D.W.; Zhang, W.-X. Zero-Valent Iron Nanoparticles for Abatement of Environmental Pollutants: Materials and Engineering Aspects. Crit. Rev. Solid State Mater. Sci. 2006, 31, 111-122. [CrossRef]

28. Guo, X.; Yang, Z.; Dong, H.; Guan, X.; Ren, Q.; Lv, X.; Jin, X. Simple combination of oxidants with zero-valent-iron (ZVI) achieved very rapid and highly efficient removal of heavy metals from water. Water Res. 2016, 88, 671-680. [CrossRef]

29. Volpe, A.; Pagano, M.; Mascolo, G.; Lopez, A.; Ciannarella, R.; Locaputo, V. Simultaneous Cr(VI) reduction and non-ionic surfactant oxidation by peroxymonosulphate and iron powder. Chemosphere 2013, 91, 1250-1256. [CrossRef]

30. Diao, Z.-H.; Qian, W.; Zhang, Z.-W.; Jin, J.-C.; Chen, Z.-L.; Guo, P.-R.; Dong, F.-X.; Yan, L.; Kong, L.-J.; Chu, W. Removals of Cr(VI) and $\mathrm{Cd}(\mathrm{II})$ by a novel nanoscale zero valent iron/peroxydisulfate process and its Fenton-like oxidation of pesticide atrazine: Coexisting effect, products and mechanism. Chem. Eng. J. 2020, 397, 125382. [CrossRef]

31. Bruzzoniti, M.C.; Fiore, S. Removal of Inorganic Contaminants from Aqueous Solutions: Evaluation of the Remediation Efficiency and of the Environmental Impact of a Zero-Valent Iron Substrate. Water Air Soil Pollut. 2014, 225, 2098. [CrossRef]

32. Zhao, L.; Ji, Y.; Kong, D.; Lu, J.; Zhou, Q.; Yin, X. Simultaneous removal of bisphenol A and phosphate in zero-valent iron activated persulfate oxidation process. Chem. Eng. J. 2016, 303, 458-466. [CrossRef]

33. Klas, S.; Kirk, D.W. Advantages of low $\mathrm{pH}$ and limited oxygenation in arsenite removal from water by zero-valent iron. J. Hazard. Mater. 2013, 252-253, 77-82. [CrossRef]

34. Gil-Díaz, M.; Diez-Pascual, S.; González, A.; Alonso, J.; Rodríguez-Valdés, E.; Rodríguez-Gallego, J.L.; Lobo, M. A nanoremediation strategy for the recovery of an As-polluted soil. Chemosphere 2016, 149, 137-145. [CrossRef]

35. Baragaño, D.; Alonso, J.; Gallego, J.; Lobo, M.; Gil-Díaz, M. Magnetite nanoparticles for the remediation of soils co-contaminated with As and PAHs. Chem. Eng. J. 2020, 399, 125809. [CrossRef]

36. Hussain, I.; Li, M.; Zhang, Y.; Huang, S.; Hayat, W.; Li, Y.; Du, X.; Liu, G. Efficient oxidation of arsenic in aqueous solution using zero valent iron- activated persulfate process. J. Environ. Chem. Eng. 2017, 5, 3983-3990. [CrossRef]

37. Brillas, E.; Garcia-Segura, S. Benchmarking recent advances and innovative technology approaches of Fenton, photo-Fenton, electro-Fenton, and related processes: A review on the relevance of phenol as model molecule. Sep. Purif. Technol. 2020, 237, 116337. [CrossRef]

38. Martins, R.C.; Henriques, L.R.; Quinta-Ferreira, R.M. Catalytic activity of low cost materials for pollutants abatement by Fenton's process. Chem. Eng. Sci. 2013, 100, 225-233. [CrossRef]

39. Lai, B.; Zhang, Y.-H.; Li, R.; Zhou, Y.-X.; Wang, J. Influence of operating temperature on the reduction of high concentration p-nitrophenol (PNP) by zero valent iron (ZVI). Chem. Eng. J. 2014, 249, 143-152. [CrossRef]

40. Segura, Y.; Martínez, F.; Melero, J.; Fierro, J. Zero valent iron (ZVI) mediated Fenton degradation of industrial wastewater: Treatment performance and characterization of final composites. Chem. Eng. J. 2015, 269, 298-305. [CrossRef]

41. Yamaguchi, R.; Kurosu, S.; Suzuki, M.; Kawase, Y. Hydroxyl radical generation by zero-valent iron/Cu (ZVI/Cu) bimetallic catalyst in wastewater treatment: Heterogeneous Fenton/Fenton-like reactions by Fenton reagents formed in-situ under oxic conditions. Chem. Eng. J. 2018, 334, 1537-1549. [CrossRef]

42. Donadelli, J.A.; Carlos, L.; Arques, A.; Einschlag, F.S. Kinetic and mechanistic analysis of azo dyes decolorization by ZVI-assisted Fenton systems: $\mathrm{pH}$-dependent shift in the contributions of reductive and oxidative transformation pathways. Appl. Catal. $B$ 2018, 231, 51-61. [CrossRef]

43. Buxton, G.V.; Greenstock, C.L.; Helman, W.P.; Ross, A.B. Critical Review of rate constants for reactions of hydrated electrons, hydrogen atoms and hydroxyl radicals $\left(\mathrm{OH} / \mathrm{O}^{-}\right.$in Aqueous Solution. J. Phys. Chem. Ref. Data 1988, 17, 513-886. [CrossRef]

44. Neta, P.; Huie, R.E.; Ross, A.B. Rate Constants for Reactions of Inorganic Radicals in Aqueous Solution. J. Phys. Chem. Ref. Data 1988, 17, 1027-1284. [CrossRef]

45. Avetta, P.; Pensato, A.; Minella, M.; Malandrino, M.; Maurino, V.; Minero, C.; Hanna, K.; Vione, D. Activation of Persulfate by Irradiated Magnetite: Implications for the Degradation of Phenol under Heterogeneous Photo-Fenton-Like Conditions. Environ. Sci. Technol. 2014, 49, 1043-1050. [CrossRef]

46. Lee, J.; Von Gunten, U.; Kim, J.-H. Persulfate-Based Advanced Oxidation: Critical Assessment of Opportunities and Roadblocks. Environ. Sci. Technol. 2020, 54, 3064-3081. [CrossRef] [PubMed]

47. Furman, O.; Teel, A.; Ahmad, M.; Merker, M.C.; Watts, R.J. Effect of Basicity on Persulfate Reactivity. J. Environ. Eng. 2011, 137, 241-247. [CrossRef]

48. Nidheesh, P.V. Heterogeneous Fenton catalysts for the abatement of organic pollutants from aqueous solution: A review. RSC Adv. 2015, 5, 40552-40577. [CrossRef]

49. Enami, S.; Sakamoto, Y.; Colussi, A.J. Fenton chemistry at aqueous interfaces. Proc. Natl. Acad. Sci. USA 2014, 111, 623-628. [CrossRef] 
50. Liu, Y.; Wang, J. Reduction of nitrate by zero valent iron (ZVI)-based materials: A review. Sci. Total Environ. 2019, 671, 388-403. [CrossRef] [PubMed]

51. Wols, B.; Hofman-Caris, C. Review of photochemical reaction constants of organic micropollutants required for UV advanced oxidation processes in water. Water Res. 2012, 46, 2815-2827. [CrossRef] [PubMed]

52. Gligorovski, S.; Strekowski, R.; Barbati, S.; Vione, D. Environmental Implications of Hydroxyl Radicals $\left({ }^{\bullet} \mathrm{OH}\right) . \mathrm{Chem}^{\mathrm{R}} \mathrm{Rev} . \mathbf{2 0 1 5}$ 115, 13051-13092. [CrossRef] [PubMed]

53. Wardman, P. Reduction Potentials of One-Electron Couples Involving Free Radicals in Aqueous Solution. J. Phys. Chem. Ref. Data 1989, 18, 1637-1755. [CrossRef]

54. Liu, H.; Chen, T.; Chang, D.; Chen, D.; Liu, Y.; He, H.; Yuan, P.; Frost, R. Nitrate reduction over nanoscale zero-valent iron prepared by hydrogen reduction of goethite. Mater. Chem. Phys. 2012, 133, 205-211. [CrossRef]

55. Ullah, S.; Guo, X.; Luo, X.; Zhang, X.; Leng, S.; Ma, N.; Faiz, P. Rapid and long-effective removal of broad-spectrum pollutants from aqueous system by ZVI/oxidants. Front. Environ. Sci. Eng. 2020, 14, 89. [CrossRef]

56. Fu, F.; Dionysiou, D.D.; Liu, H. The use of zero-valent iron for groundwater remediation and wastewater treatment: A review. J. Hazard. Mater. 2014, 267, 194-205. [CrossRef]

57. Zhang, X.; Lin, S.; Chen, Z.; Megharaj, M.; Naidu, R. Kaolinite-supported nanoscale zero-valent iron for removal of Pb ${ }^{2+}$ from aqueous solution: Reactivity, characterization and mechanism. Water Res. 2011, 45, 3481-3488. [CrossRef] [PubMed]

58. Luo, S.; Qin, P.; Shao, J.; Peng, L.; Zeng, Q.; Gu, J.-D. Synthesis of reactive nanoscale zero valent iron using rectorite supports and its application for Orange II removal. Chem. Eng. J. 2013, 223, 1-7. [CrossRef]

59. Zhang, Y.; Zhao, L.; Yang, Y.; Sun, P. Degradation of Norfloxacin in an Aqueous Solution by the Nanoscale Zero-Valent Iron-Activated Persulfate Process. J. Nanomater. 2020, 2020, 3286383. [CrossRef]

60. Dong, H.; Ning, Q.; Li, L.; Wang, Y.; Wang, B.; Zhang, L.; Tian, R.; Li, R.; Chen, J.; Xie, Q. A comparative study on the activation of persulfate by bare and surface-stabilized nanoscale zero-valent iron for the removal of sulfamethazine. Sep. Purif. Technol. 2020, 230, 115869. [CrossRef]

61. Litter, M.I.; Slodowicz, M. An overview on heterogeneous Fenton and photoFenton reactions using zerovalent iron materials. J. Adv. Oxid. Technol. 2017, 20. [CrossRef]

62. Minella, M.; Sappa, E.; Hanna, K.; Barsotti, F.; Maurino, V.; Minero, C.; Vione, D. Considerable Fenton and photo-Fenton reactivity of passivated zero-valent iron. RSC Adv. 2016, 6, 86752-86761. [CrossRef]

63. Furina, F.; Minella, M.; Gosetti, F.; Turci, F.; Sabatino, R.; Di Cesare, A.; Corno, G.; Vione, D. Elimination from wastewater of antibiotics reserved for hospital settings, with a Fenton process based on zero-valent iron. Chemosphere 2021, 283 , 131170. [CrossRef]

64. Liang, S.X.; Jia, Z.; Liu, Y.J.; Zhang, W.; Wang, W.; Lu, J.; Zhang, L.C. Compelling rejuvenated catalytic performance in metallic glasses. Adv. Mater. 2018, 30, 1802764. [CrossRef]

65. Liang, S.; Jia, Z.; Zhang, L.; Li, X.; Wang, W.; Lin, H. Ultrafast activation efficiency of three peroxides by Fe78Si9B13 metallic glass under photo-enhanced catalytic oxidation: A comparative study. Appl. Catal. B Environ. 2018, 221, 108-118. [CrossRef]

66. Zhang, L.-C.; Jia, Z.; Lyu, F.; Liang, S.-X.; Lu, J. A review of catalytic performance of metallic glasses in wastewater treatment: Recent progress and prospects. Prog. Mater. Sci. 2019, 105, 100576. [CrossRef]

67. Liang, S.-X.; Wang, X.; Zhang, W.; Liu, Y.-J.; Wang, W.; Zhang, L.-C. Selective laser melting manufactured porous Fe-based metallic glass matrix composite with remarkable catalytic activity and reusability. Appl. Mater. Today 2020, 19, 100543. [CrossRef]

68. Deng, J.; Shao, Y.; Gao, N.; Deng, Y.; Tan, C.; Zhou, S. Zero-valent iron/persulfate(Fe0/PS) oxidation acetaminophen in water. Int. J. Environ. Sci. Technol. 2013, 11, 881-890. [CrossRef]

69. Minella, M.; Bertinetti, S.; Hanna, K.; Minero, C.; Vione, D. Degradation of ibuprofen and phenol with a Fenton-like process triggered by zero-valent iron (ZVI-Fenton). Environ. Res. 2019, 179, 108750. [CrossRef]

70. Jiang, X.; Wu, Y.; Wang, P.; Li, H.; Dong, W. Degradation of bisphenol A in aqueous solution by persulfate activated with ferrous ion. Environ. Sci. Pollut. Res. 2013, 20, 4947-4953. [CrossRef] [PubMed]

71. Wang, T.; Lin, J.; Chen, Z.; Megharaj, M.; Naidu, R. Green synthesized iron nanoparticles by green tea and eucalyptus leaves extracts used for removal of nitrate in aqueous solution. J. Clean. Prod. 2014, 83, 413-419. [CrossRef]

72. Wu, J.; Wang, B.; Cagnetta, G.; Huang, J.; Wang, Y.; Deng, S.; Yu, G. Nanoscale zero valent iron-activated persulfate coupled with Fenton oxidation process for typical pharmaceuticals and personal care products degradation. Sep. Purif. Technol. 2020, 239, 116534. [CrossRef]

73. Zhang, T.; Yang, Y.; Gao, J.; Li, X.; Yu, H.; Wang, N.; Du, P.; Yu, R.; Li, H.; Fan, X.; et al. Synergistic degradation of chloramphenicol by ultrasound-enhanced nanoscale zero-valent iron/persulfate treatment. Sep. Purif. Technol. 2020, 240, 116575. [CrossRef]

74. Du, Y.; Dai, M.; Cao, J.; Peng, C.; Ali, D.I.; Naz, I.; Li, J. Efficient removal of acid orange 7 using a porous adsorbent-supported zero-valent iron as a synergistic catalyst in advanced oxidation process. Chemosphere 2020, 244, 125522. [CrossRef]

75. Liu, H.; Yao, J.; Wang, L.; Wang, X.; Qu, R.; Wang, Z. Effective degradation of fenitrothion by zero-valent iron powder (Fe0) activated persulfate in aqueous solution: Kinetic study and product identification. Chem. Eng. J. 2019, 358, 1479-1488. [CrossRef]

76. Zou, X.; Zhou, T.; Mao, J.; Wu, X. Synergistic degradation of antibiotic sulfadiazine in a heterogeneous ultrasound-enhanced Fe0/persulfate Fenton-like system. Chem. Eng. J. 2014, 257, 36-44. [CrossRef]

77. Tan, C.; Gao, N.; Chu, W.; Li, C.; Templeton, M.R. Degradation of diuron by persulfate activated with ferrous ion. Sep. Purif. Technol. 2012, 95, 44-48. [CrossRef] 
78. Jiang, Z.; Li, J.; Jiang, D.; Gao, Y.; Chen, Y.; Wang, W.; Cao, B.; Tao, Y.; Wang, L.; Zhang, Y. Removal of atrazine by biocharsupported zero-valent iron catalyzed persulfate oxidation: Reactivity, radical production and transformation pathway. Environ. Res. 2020, 184, 109260. [CrossRef]

79. Nie, M.; Yan, C.; Li, M.; Wang, X.; Bi, W.; Dong, W. Degradation of chloramphenicol by persulfate activated by Fe $\mathrm{Fe}^{2+}$ and zerovalent iron. Chem. Eng. J. 2015, 279, 507-515. [CrossRef]

80. Dong, S.; Zhai, X.; Pi, R.; Wei, J.; Wang, Y.; Sun, X. Efficient degradation of naproxen by persulfate activated with zero-valent iron: Performance, kinetic and degradation pathways. Water Sci. Technol. 2020, 81, 2078-2091. [CrossRef]

81. Qiao, J.; Jiao, W.; Liu, Y. Degradation of nitrobenzene-containing wastewater by sequential nanoscale zero valent iron-persulfate process. Green Energy Environ. 2020. [CrossRef]

82. Gao, C.; Yu, W.; Zhu, Y.; Wang, M.; Tang, Z.; Du, L.; Hu, M.; Fang, L.; Xiao, X. Preparation of porous silicate supported micro-nano zero-valent iron from copper slag and used as persulfate activator for removing organic contaminants. Sci. Total Environ. 2021, 754, 142131. [CrossRef] [PubMed]

83. Gao, Y.-Q.; Gao, N.-Y.; Wang, W.; Kang, S.; Xu, J.-H.; Xiang, H.-M.; Yin, D.-Q. Ultrasound-assisted heterogeneous activation of persulfate by nano zero-valent iron (nZVI) for the propranolol degradation in water. Ultrason. Sonochemistry 2018, 49, 33-40. [CrossRef] [PubMed]

84. Hussain, I.; Zhang, Y.; Huang, S.; Du, X. Degradation of p-chloroaniline by persulfate activated with zero-valent iron. Chem. Eng. J. 2012, 203, 269-276. [CrossRef]

85. Hayat, W.; Zhang, Y.; Hussain, I.; Du, X.; Du, M.; Yao, C.; Huang, S.; Si, F. Efficient degradation of imidacloprid in water through iron activated sodium persulfate. Chem. Eng. J. 2019, 370, 1169-1180. [CrossRef]

86. Le, C.; Wu, J.-H.; Li, P.; Wang, X.; Zhu, N.-W.; Wu, P.; Yang, B. Decolorization of anthraquinone dye Reactive Blue 19 by the combination of persulfate and zero-valent iron. Water Sci. Technol. 2011, 64, 754-759. [CrossRef] [PubMed]

87. Wei, X.; Gao, N.; Li, C.; Deng, Y.; Zhou, S.; Li, L. Zero-valent iron (ZVI) activation of persulfate (PS) for oxidation of bentazon in water. Chem. Eng. J. 2016, 285, 660-670. [CrossRef]

88. Lutze, H.V.; Kerlin, N.; Schmidt, T.C. Sulfate radical-based water treatment in presence of chloride: Formation of chlorate, inter-conversion of sulfate radicals into hydroxyl radicals and influence of bicarbonate. Water Res. 2015, 72, 349-360. [CrossRef]

89. Kim, C.; Thao, T.T.; Kim, J.-H.; Hwang, I. Effects of the formation of reactive chlorine species on oxidation process using persulfate and nano zero-valent iron. Chemosphere 2020, 250, 126266. [CrossRef]

90. Rayaroth, M.P.; Lee, C.-S.; Aravind, U.K.; Aravindakumar, C.T.; Chang, Y.-S. Oxidative degradation of benzoic acid using Fe ${ }^{0}$ and sulfidized Fe 0 -activated persulfate: A comparative study. Chem. Eng. J. 2017, 315, 426-436. [CrossRef]

91. Vione, D.; Maurino, V.; Minero, C.; Calza, P.; Pelizzetti, E. Phenol Chlorination and Photochlorination in the Presence of Chloride Ions in Homogeneous Aqueous Solution. Environ. Sci. Technol. 2005, 39, 5066-5075. [CrossRef]

92. Yuan, R.; Wang, Z.; Hu, Y.; Wang, B.; Gao, S. Probing the radical chemistry in UV/persulfate-based saline wastewater treatment: Kinetics modeling and byproducts identification. Chemosphere 2014, 109, 106-112. [CrossRef]

93. Bu, L.; Sun, J.; Wu, Y.; Zhang, W.; Duan, X.; Zhou, S.; Dionysiou, D.; Crittenden, J.C. Non-negligible risk of chloropicrin formation during chlorination with the UV/persulfate pretreatment process in the presence of low concentrations of nitrite. Water Res. 2020, 168, 115194. [CrossRef]

94. Bu, L.; Zhou, S.; Zhu, S.; Wu, Y.; Duan, X.; Shi, Z.; Dionysiou, D.D. Insight into carbamazepine degradation by UV/monochloramine: Reaction mechanism, oxidation products, and DBPs formation. Water Res. 2018, 146, $288-297$. [CrossRef]

95. Chu, W.; Ding, S.; Bond, T.; Gao, N.; Yin, D.; Xu, B.; Cao, Z. Zero valent iron produces dichloroacetamide from chloramphenicol antibiotics in the absence of chlorine and chloramines. Water Res. 2016, 104, 254-261. [CrossRef]

96. Zhao, X.; Zhang, T.; Lu, J.; Zhou, L.; Chovelon, J.-M.; Ji, Y. Formation of chloronitrophenols upon sulfate radical-based oxidation of 2-chlorophenol in the presence of nitrite. Environ. Pollut. 2020, 261, 114242. [CrossRef]

97. Wang, Q.; Shao, Y.; Gao, N.; Liu, S.; Dong, L.; Rao, P.; Chu, W.; Xu, B.; An, N.; Deng, J. Impact of zero valent iron/persulfate preoxidation on disinfection byproducts through chlorination of alachlor. Chem. Eng. J. 2020, 380, 122435. [CrossRef]

98. Wang, Q.; Shao, Y.; Gao, N.; Chu, W.; Chen, J.; Lu, X.; Zhu, Y.; An, N. Impact of preoxidation of UV/persulfate on disinfection byproducts by chlorination of 2,4-Di-tert-butylphenol. J. Hazard. Mater. 2018, 358, 450-458. [CrossRef]

99. Bennedsen, L.R.; Muff, J.; Søgaard, E.G. Influence of chloride and carbonates on the reactivity of activated persulfate. Chemosphere 2012, 86, 1092-1097. [CrossRef]

100. Ma, J.; Li, H.; Yang, Y.; Li, X. Influence of water matrix species on persulfate oxidation of phenol: Reaction kinetics and formation of undesired degradation byproducts. Water Sci. Technol. 2018, 2017, 340-350. [CrossRef]

101. Lei, Y.; Chen, C.-S.; Ai, J.; Lin, H.; Huang, Y.-H.; Zhang, H. Selective decolorization of cationic dyes by peroxymonosulfate: Non-radical mechanism and effect of chloride. RSC Adv. 2015, 6, 866-871. [CrossRef]

102. Guo, W.; Zhao, Q.; Du, J.; Wang, H.; Li, X.; Ren, N. Enhanced removal of sulfadiazine by sulfidated ZVI activated persulfate process: Performance, mechanisms and degradation pathways. Chem. Eng. J. 2020, 388, 124303. [CrossRef]

103. Ao, X.; Liu, W. Degradation of sulfamethoxazole by medium pressure UV and oxidants: Peroxymonosulfate, persulfate, and hydrogen peroxide. Chem. Eng. J. 2017, 313, 629-637. [CrossRef]

104. Ji, Y.; Kong, D.; Lu, J.; Jin, H.; Kang, F.; Yin, X.; Zhou, Q. Cobalt catalyzed peroxymonosulfate oxidation of tetrabromobisphenol A: Kinetics, reaction pathways, and formation of brominated by-products. J. Hazard. Mater. 2016, 313, 229-237. [CrossRef] 